\title{
TÜRKÇE-KİRMANCCA (ZAZACA) SÖZLÜK BAĞLAMINDA ZAZACADA EŞANLAMLI SÖZCÜKLER*
}

\section{Ahmet Kırkan**}

\section{$\ddot{\mathbf{O z}}$}

Dillerde eş anlamlı sözcükler zenginleştirici öğelerdir. Bazı dillerde bir sözcügün birden çok eş anlamlısı bulunurken, bazı dillerde ise sözcüklerin eş anlamları çok az vardır veya hiç yoktur. Eş anlamlı sözcükler aynı kavramı farklı açılardan tanımlayan, kavramın çeşitli yönlerini ortaya koyan sözcüklerdir. Kürtçede ve özellikle Zazaca diyalektinde eş anlamlı sözcükler yoğun bir şekilde kullanılmaktadır. Eş anlamlı olarak belirtilen bütün sözcüklerde nüanslar vardır. Bu sözcükler genel yapı anlam ilişkisi içerisinde eş anlamlı olarak kabul edilirler. Özellikle farklı kültürlerin ve dillerin iç içe geçtiği coğrafyalarda eş anlamlı sözcüklerin sayısında ciddi bir artış meydana gelir. Konuşulduğu coğrafya göz önüne alındığında Zazaca; Türkçe, Arapça ve Farsça dilleri ile Kurmancca diyalektiğinin mozaik bir yapı oluşturduğu bir coğrafyada konuşulmaktadır. Bu kültürel mozaik ve dilsel atlas Zazacada birçok eşanlamlı sözcügün ortaya çıkmasını sağlamıştır. Çalışmanın amacı Vate Çalışma Grubu tarafından hazırlanmış olan sözlükte, Zazacadaki eş anlamlı sözcükleri tespit etmek; bu sözcükleri anlamsal açıdan analiz etmek ve hangi seslerde daha fazla eş anlamlı sözcüğün bulunduğunu grafiklerle tespit etmektir. Kaynak olarak bahsedilen sözlük ve çeşitli dillerdeki dilbilim kaynakları kullanılacaktır. Türkçede bu alanda birçok çalışma yapılmış olmasına rağmen Zazacada bu alanda şimdiye kadar müstakil bir çalışma yapılmamıştır. $\mathrm{Bu}$ açıdan çalışma önem arz etmektedir. Kaybolmaya yüz tutmuş bir dilde yapılacak kategorik çalışmalar, dilin envanterinin ortaya konulması açısından önemlidir. Zazacada tespit edilmiş eş anlamlı sözcükler, çalışmanın sonunda verilmiştir. Çalışmada günlük dilde aktif bir ş̧ekilde konuşulan sözcüklerin tespit edilmesine özen gösterilmiş, yabancı dillerden alınmış veya türetilmiş sözcükler çalışmaya alınmamıştır.

Anahtar kelimeler: Zazaca, Eş anlam, Dilbilim, Vate Çalışma Grubu, Kürtçe

\footnotetext{
* Araştırma makalesi/Research article

** Dr. Öğr. Üyesi, Mardin Artuklu Üniversitesi, Edebiyat Fakültesi, Kürt Dili ve Edebiyatı bölümü, e-posta: ahmetkirkan@gmail.com, Orcid: 0000-0003-3885-5218 Makale Gönderim Tarihi: 21.09.2020

Makale Kabul Tarihi $\quad$ : 19.12 .2020

NÜSHA, 2020; (51): 161-196
} 


\title{
Synonyms in Zazaki in the Context of the Turkish-Kirmancki (Zazaki) Dictionary
}

\begin{abstract}
Synonym words in languages are enriching items. While some languages have more than one synonym for a word, in other languages words have few or no synonyms. Synonyms are words that describe the same concept from different angles and reveal various aspects of the concept. Synonymous words are used extensively in Kurdish and especially in the Zazaki dialect. All words specified as synonyms have nuances. These words are accepted as synonyms within the general structure-meaning relationship. Especially in geographies where different cultures and languages are intertwined, a serious increase occurs in the number of synonyms. Considering the geography it is spoken in, Zazaki; Turkish, Arabic and Persian languages are spoken in a geography where the Kurmanji dialectic forms a mosaic structure. This cultural mosaic and linguistic atlas led to the emergence of many synonym words in Zazaki. The aim of the study is to identify synonyms in Zazaki in the dictionary prepared by the Vate Study Group; To analyze these words semantically and to determine with graphics in which sounds have more synonyms. The mentioned dictionary and linguistic resources in various languages will be used as sources. Although there have been many studies in this field in Turkish, there has not been an independent study in this field in Zazaki until now. In this respect, the study is important. Categorical studies to be conducted in a language that is about to disappear are important in terms of revealing the inventory of the language. The synonyms determined in Zazaki are given at the end of the study. In the study, care was taken to identify the words actively spoken in the daily language, words taken from or derived from foreign languages were not included in the study.
\end{abstract}

Keywords: Zazaki, Synonym, Linguistics, Vate Study Group, Kurdish

\section{Structured Abstract}

Most languages have synonyms. Synonymity is the use of interchangeable words to meet the same concept. Words that are called synonyms in logical propositions must be used interchangeably. Words that are not used interchangeably and that do not overlap semantically are not considered synonyms. Synonym words are based on meaning, and meaning is an abstract and subjective concept. Since the meaning is abstract and subjective, it cannot be stated that there is a complete harmony between different words. Synonyms and synonyms are the opposite of each other. Synonyms words are close to each other in meaning. In some of the synonym words, a very meaningful word develops in terms of meaning, the relationship between the old meaning and the new meaning is broken, and homosexual words emerge. In order for synonyms 
to fulfill this requirement, they must be close in meaning. Words whose meaning is not clear and that are not actively used by language speakers cannot be regarded as synonyms. Some of these words do not settle in the language, speakers of the language do not adopt these words. The same is true for Turkish after the language revolution. The words that were put forward or produced during this period became obsolete after a while.

Generally, words with similar meanings are shown as synonyms in Zazaki dictionaries. This situation is the same in different languages. Methods such as using the word with different sentences can be followed to reveal that these words do not have the same meaning or are not exactly the same. Synonyms vary according to context, time and geography. When the context changes, words that are considered synonyms can cease to be synonyms. One of the dynamics that causes synonyms to change is time. Over time, words undergo changes. These changes are not just phonologically. Semantic changes also occur in words. Phonological changes can occur in a short time and can be easily detected. But the changes that occur in the meaning of the words occur over a longer period of time and cannot be easily noticed. One of the dynamics that causes synonyms to change is geography. Geography is an important factor in the differentiation of synonyms in a dialect such as Zazaki, where local differences especially among language speakers reach the level of not understanding each other.

There are sometimes big and sometimes small differences between the words that are considered synonymous in every language. It is necessary to define the words with great differences as closely related words or to determine the meaning limits of these words. Although some of the synonyms in Zazaki are grouped under the same article in the dictionary, there is a close meaning relationship between them. The criterion we use when choosing these words is that the words specified as synonyms are actively used by the speakers of the language in both words rather than being of foreign origin or Zazaki origin. In the studies of creating the Zazaki standard language, the Zazaki equivalents of some foreign words are determined or these words are made.

In the study, the origins of 10 words that are regarded as synonyms and their relationships with each other were examined. Since the aim of the study is to examine the synonyms in Zazaki, the words examined here reveal the semantic link between the words that are synonymous. In the statistics section, synonyms in Zazaki were analyzed according to the sounds in the alphabet and the number of repetitions. In the appendix part of the study, synonyms are listed in alphabetical order. In total, about 490 synonyms were identified for the study. The study has been completed with the conclusion part. Many books have been used in the study. 


\section{Giriş}

Dillerin birç̧oğunda eş anlamlı sözcükler bulunur. Eş anlamlllık, birbiri yerine kullanılabilen sözcüklerin aynı kavramı karşılamak için kullanılmasıdır. Eş anlamlılık genellikle dillerin kaçındığ bir durumdur (Murphy, 2006, 376). Başka bir deyişle eş anlamlılık, iki veya daha fazla gösterenin tek bir gösterilene göndermede bulunmasıdır (Kıran\&Eziler Kıran, 2013, 198). Eş anlamlı sözcükler arasında semantik açıdan çeşitli anlam ilişkileri vardır. Bu sözcükler çoğu kez birbirinin yerine kullanılabilir veya aynı anlam çağrışımlarına sahiptirler. Bu sözcükler bazı semantik bağlamlarda farklı olarak kullanılsalar da, aralarındaki yakın ilişkiden dolayı eş anlamlı olarak adlandırılırlar. Eş anlamlılık, sözcük gruplarının kendi aralarındaki semantik ilişkiye göre de değişir (Crystal, 2008, 470). Mantıksal önermelerde eş anlamlı olarak adlandırılan sözcüklerin birbirinin yerine kullanılabilir olması gerekir (Ahanov, 2013, 123). Birbirinin yerine kullanılmayan ve semantik açıdan örtüşmeyen sözcükler eş anlamlı olarak kabul edilmezler (Murphy, 2006, 376).

İngilizcede synonym, Arapçada müteradif (Mutçal1, 2013, 357), Farsçada müteradif (Kanar, 2010, 1357), Türkçede eş anlamlı (Akalın, 2011, 822) olarak adlandırılan eş anlamlı sözcükler Kurmancca diyalektinde hevwate ve Zazacada ise hemmana olarak isimlendirilir. Dillerde farklı olarak adlandırılmıș olsalar da eş anlamlılık aynı şeyi ifade eder. Eş anlamlılık leksikal semantiğin incelediği bir alandır. Doğan Aksan bu alan için sözcük anlam bilimini ifadesini kullanmıştır ki bu bilim dalı eş anlamlı, zit anlamlı, çok anlamlı sözcükleri inceler (Aksan, 1998). Her ne kadar sözcüklerde anlam benzerliği eş anlamlılık olarak adlandırılsa da, bu sözcüklerin kendi aralarında belli seviyelere ayrılırlar. Birbiriyle anlamsal açıdan tam örtüşen eş anlamlı sözcükler absolutely synonymous olarak adlandırılır (Crystal, 2008, 28). Bu sözcükler arasında anlamsal açıdan tam bir uyum vardır. Sarı'nın (2012) Frank Robert Palmer'den naklettiğine göre dildeki sözcükler arasında semantik açıdan birbiriyle tam örtüşen iki sözcük bulunmaz. Ahanov da aynı şeyi ifade etmektedir (Ahanov, 2013, 123). Çalışmada ifade edileceği üzere, eş anlamlı sözcüklerin çoğu, belirttikleri kavramın farklı yönlerini ifade ederler. Örnek olarak Zazacada asa sözcügünü karşılayan çogane $(m)$, esa $(m)$, çanqil $(n)$, uşîre $(m)$ sözcüklerinden her birisi kavramın farklı bir özelliğini belirtir (Grûba Xebata ya Vateyî, 2019). Bu sözcükler aynı olmaktan ziyade, anlamca yakınlık belirtir. Dillerde kavramı aynı şekilde belirtecek ve birbirinin yerine kullanılabilecek sözcük sayısı çok azdır (Vardar 1998, 97). Sözcüklerde önemli olan kullanım yani konteksttir. Sözcüklerin anlamı cümledeki kullanımlarına göre belirlenir. Sözcüklerin anlamı belirttikleri kavramla beraber ortaya çıkar. Kullanıma bağlı olarak eş anlamlı sözcükler zaman içerisinde değişir ve hatta ortadan kalkarlar (Sarı, 2012, 2220-2221). Eş anlamlı sözcüklerle eş sesli sözcükler birbirinin karşıtıdır. Eş anlamlı sözcükler anlam bakımından birbirine yakındır. Eş sesli sözcüklerin bir kısmında çok anlamlı bir sözcük anlam bakımından gelişir, eski anlamla 
yeni anlam arasındaki ilişki kopar ve eş sesli sözcükler ortaya çıkar. Eş anlamlı sözcüklerin bu şartı sağlayabilmesi için anlam bakımından yakın olmaları gerekir (Karaağaç, 2013, 373-374; Ahanov, 2013, 122). Aslında eş anlamlılık dildeki en az çaba yasasına aykırıdır (Hengirmen, 2009, 158-159).

Eş anlamlılık Zazacada yeterince incelenmiş bir konu değildir. Gramer kitaplarında sözcük türleri işlenirken, anlamlarına göre sözcük türlerinde eş anlamlı sözcüklere birkaç tane örnek verilmiş ve bu konu üzerinde çok durulmamıştır. Eş anlamlı sözcüklerin (fonolojik ve sentaktik düzeyde) varlıkları dilbiliminde tartışma konusudur. Bazı dilbilimciler farklı anlamlara sahip sözcüklerin zamanla aynı anlama gelebildiklerini ifade ederken, Bloomfield biçim yönünden farklı sözcüklerin anlam yönünden de farklı olması gerektiğini ifade etmişlerdir (Aksan, 1974, 1-2). Diğer bazı dilbilimciler ise eş anlamlı olarak belirtilen sözcükler arasında anlamsal olarak nüansların olduğunu ifade etmektedirler. Abouelnasr (2004) Tanrı'nın aynı anlamlı sözcüklerle kural koymasının mümkün olmadığını ifade etmiş ve eş anlamlılı̆̆ın önünü kapatmıştır. Ama bilindiği kadarıyla Kur'an'da muhkem ve müteşabih olmak üzere iki kavram vardır ve bu kavramlardan müteşabih, eş anlamlı olmaya yakın bir kavramdır. Aynı şekilde bazı dilbilimciler eş anlamlılığın fonolojik düzeyde ve sözcükler arasında gerçekleştiğini ifade ederler (Korkmaz 1992, 56; Vardar, 2002, 94). Bazı dilbilimciler için ise bu sınır daha genişti. Bunlar sentaktik yani cümleler arasında eş anlamlılık olabileceğini (İmer vd. 2011, 118) ifade ederken Bussmann ise dilsel ifadeler arasında da eş anlamlı sözcük ve ifadelerin bulunabileceğini belirtir (Bussmann, 2006, 1164).

Eş anlamlı sözcüklerin temelinde anlam vardır ve anlam soyut ve öznel bir kavramdır. Anlam soyut ve öznel olduğundan, farklı sözcükler arasında anlamsal açıdan tam bir uyumun olduğu ifade edilemez. Ancak eş anlamlı sözcükler arasında güçlü bir anlam benzerliği vardır (Sert, 2019, 94-95). Yabancı dillerden, dile geçmiş olan alıntı sözcüklerin eş anlamlı olup olmadığı sorunu da konunun farklı bir yönüdür. Bazı dilbilimciler yabancı dillerden alıntılanmış sözcüklerin eş anlamlı sayılmaması gerektiğini ifade etmişlerdir. Ama yabancı dillerden alıntılanan veya doğal süreç içerisinde dile geçmiş olan sözcükler anlam değişmesine uğradıkları ve anlam alanlarını değiştirdikleri için eş anlamlılığı ifade ederler (Günay, 2015, 122). Bunlar kısmi eş anlamlı olarak kabul edilebilir. Alıntılanmış olan sözcüklerin tam olarak yerleşmiş olması gerekir. Dile yerleşmemiş olan sözcüklerle kurulacak olan anlam ilişkisi anlam bulanıklığına neden olur. Çünkü alıntılanan sözcügün anlam sınırlarını tam olarak çizilmesi lazımdır. Sert'in aktardığına göre Palmer, eş anlamlılığı sınamak amaciyla üç ölçüt belirlemiştir. Bunlardan birincisi eş anlamlı olduğu varsayılan sözcüklerin birbiriyle yer değiştirip değiştirememesidir (Sert, 2019, 99-100). Bu ölçüte Zazacadaki bazı sözcüklerde bütüncül eş anlamlılık varken 
bazı sözcüklerde ise klsmi eş anlamlılık ilişkisi göze çarpar. İkinci ölçüt eş anlamlı olarak belirtilen sözcüklerin, zıt anlamlılarının da özdeş olması gerekir (Sert, 2019, 100). Bu ölçüt Zazacada, tespit edildiği kadarıyla Türkçe, Arapça, Farsça, Kurmancca gibi diğer dillerde de, tam anlamıyla yerine gelmemektedir. Palmer'in belirlediği kriterlerden üçüncüsü ve sonuncusu eş anlamlı sözcüklerden her birinin aynı duygusal çağrışımları yansıtmalarıdır (Sert, 2019, 100). Zazaca eş anlamlı sözcükler bazen aynı duyguyu yansıtmayabilirler.

Eş anlamlı sözcüklerin anlam bakımından yakın veya benzer olmasının yanı sıra tamamının aynı söz türünden olması da şarttır. Farklı söz türlerinden olan sözcükler eş anlamlı olarak kabul edilemezler. Her söz türünde eş anlamlı sözcükler vardır (Ahanov, 2013, 122). Genellikle Zazaca sözlüklerde birbirine yakın anlamdaki sözcükler eş anlamlı olarak gösterilmiştir. Bu durum farklı dillerde de aynı şekildedir. Bu sözcüklerin aynı anlamı taşımadıklarını veya tamamen aynı olmadıklarını ortaya koymak için sözcüğü farklı cümlelerle beraber kullanmak gibi yöntemler takip edilebilir (Sar1, 2012, 2221). Her dilin farklı lehçeleri, şiveleri veya ağızları vardır. Eş anlamlı olarak kabul edilen ve sözlüklerde eș anlamlı olarak gösterilen bazı sözcükler, Zazaca konușulan bölgelerdeki allomorflardan oluşurlar. Örnek olarak amca sözcügünü karşılayan dat (n), ded (n) sözcükleri bölgesel farklılıklardan dolayı iki şekilde ortaya çıkmışlardır. Bu sözcükler eş anlamlı olarak kabul edilebilir ama bu sözcükler allomorfturlar. Aynı şekilde Zazacada karınca sözcügünü karşılayan 30'dan fazla allomorf vardır. Bazı eş anlamlı sözcükler ise ancak farklı bağlamlarda kullanıldıklarında doğru anlamı ifade ederler (Sarı, 2012, 2221). Zazacada ölmek anlamına gelen birçok sözcük vardır ve bu sözcüklerin her biri farklı bağlamlar ifade eder.

Buna göre eş anlamlı sözcükler bağlama göre, zamana göre ve coğrafyaya göre değiş̧iklik göstermektedirler. Bağlam değiştiği zaman, eş anlamlı olarak kabul edilen sözcükler, eş anlamlı olmaktan çıkabilirler. Zazacada tal ve tuj sözcükleri acılığı ifade ederler. Ama bu sözcüklerden birisi patlıcan, salatalık, acur gibi sebzelerin acılı̆̆ını ifade ederken, ikincisi daha çok biber gibi sebzelerin acılı̆̆ını ifade eder. Aynı şekilde çokluğu ifade etmek için kullanılan zaf, bol, zîyade, gelek, xeylê, vêşî sözcüklerinden (zarflarından) her biri ayrı bağlamlarda kullanılırlar (Grûba Xebata ya Vateyî, 2019). Misale Ez to ra zaf hes kena (Ben seni çok seviyorum.) denilebilir ama Ez to ra zîyade hes kena denilmesi çok uygun değildir. Aynı anlama gelen ve eş anlamlı olarak kategorize edilen iki sözcük, bağlamın değişmesiyle beraber farklılaşmaya başlamışlardır.

Eş anlamlı sözcüklerin değişmesine neden olan dinamiklerden biriside zamandır. Zaman içerisinde sözcüklerde değişimler uğrarlar. Meydana gelen bu değişimler sadece fonolojik olarak değildir. Sözcüklerde semantik değişimler de meydana gelir. Fonolojik olarak değişimler kısa sürede meydana gelebilir ve rahat bir şekilde tespit edilebilir. Ama sözcüklerin anlamlarında meydan gelen değişmeler daha uzun bir süreçte meydana gelir ve kolayca fark edilemezler. 
Zazacada anı ifade eden sözcüklerden birisi olan linge (m) sözcügünün tarihsel süreç içerisinde nasıl anı ifade etmeye başladığı tespit etmek güçtür. Çünkü linge sözcüğ̈̈ temel olarak ayak kavramını ifade eder (Grûba Xebata ya Vateyî, 2019). Ama süreç içerisinde temel anlamından farklı bir anlam kazanmıştır.

Eş anlamlı sözcüklerin değişmesine neden olan dinamiklerden birisi de coğrafyadır. Zazaca gibi özellikle dili konuşanlar arasında yöresel farklılıkların birbirini anlamama boyutuna ulaştığı bir diyalektte coğrafya eş anlamlı sözcüklerin farklılaşmasında önemli bir faktördür. Zazacada bazı sözcüklerde aynı sözcügün varyantları çok ciddi çeşitlilik ve farklılık gösterebilir (Grûba Xebata ya Vateyî, 2019). Zazaca konuşulan bölgeler arasında kültürel faaliyetlerin eksik olması ve bu bölgelerin izole olması, eş anlamlı sözcüklerde ve diğer sözcüklerde varyantların meydana gelmesine neden olmuştur. Bununla beraber, Zazaların yaşadıkları coğrafyada birden çok kültürün, dilin, dinin, milletin vb. etkisinin olması, Zazacada eş anlamlı sözcüklerin zengin bir yekûn ortaya çıkarmasını sağlamıştır.

\section{Zazacadaki Eş Anlamlı Sözcükler}

Her dilde eş anlamlı olarak kabul edilen sözcükler arasında bazen büyük bazen de küçük farklılklar göze çarpar. Büyük farklılıkların olduğu sözcükleri yakın anlamlı sözcük olarak tanımlamak veya bu sözcüklerin anlam sınırlarını belirlemek gerekir. Zazacadaki eş anlamlı sözcüklerin bazısı, sözlükte aynı madde altında toplanmış olsa da, aralarında yakın anlam ilişkisi vardır. Bu sözcükleri seçerken kullandığımız ölçüt, eş anlamlı olarak belirtilen sözcüklerin yabancı kökenli veya Zazaca kökenli olmasından ziyade, her iki sözcüğünde dilin konuşanları tarafından aktif bir şekilde kullanılmasıdır. Zazaca standart dili oluşturma çalışmalarında bazı yabancı kökenli sözcüklerin Zazaca karşılıkları tespit edilmekte ya da bu sözcükler yapılmaktadır. Türkçedeki örnekler göz önüne alınıp, yeni yapılmış (uydurulmuş) sözcükler, eş anlamlı olarak kabul edilemez. Örneğin, akımölçer için kullanılan amperpeym (n) ve ampermetre (n); dansimetre için kullanılan kesafetpeym (n) ve dansîmetre (n); fotometre için kullanılan roşnapeym (n), roştîpeym (n) ve fotometre (n); gerçeküstü için kullanılan serrastîye $(\mathrm{m})$ ve surrealîte $(\mathrm{m})$; kilometre için kullanılan hezarmetre (n) ve kîlometre (n); timsah için kullanılan tîmsah, ve krokodîl vb. sözcükler arasında eş anlamlılık ilişkisi yoktur (Grûba Xebata ya Vateyî, 2019). Bu sözcüklerden birisi yabancı dilden alıntılanmış, diğeri ise Zazacaya uyarlanmıştır. Anlam sınırı tam belli olmayan ve dili konuşanlar tarafından aktif bir şekilde kullanılmayan sözcüklerin eş anlamlı sayılamayacağı yukarıda ifade edilmişti. Bu sözcüklerden bazıları dile yerleşmemekte, dili konuşanlar bu sözcükleri benimsememektedir. Aynı durum dil devrimi sonrasında Türkçe için de geçerlidir. Bu dönemde ortaya atılan veya üretilen sözcükler bir süre sonra tedavülden kalkmıştır. 
Dilin etkisinde kaldığı dil veya dil ailesi alıntı sözcüklerin alındığı dile işaret eder. Zazaca daha fazla Arapça ve Farsçanın etkisinde kalmıştır. Bundan dolayı Arapça ve Farsça birçok sözcük yer almış ve zaman içerisinde bu sözcüklerin Zazaca karşılıkları ortaya çıkmıştır. Son dönemlerde özellikle teknolojiyle ilgili sözcükler batı dillerinden alıntılanmaktadır. Grûba Xebata ya Vateyî'nin hazırlamış olduğu sözlük incelendiğinde teknoloji ve bilişimle ilgili neredeyse bütün sözcükler batı dillerinden alıntılanmıştır. Aşağıda Zazacada yer alan eş anlamlı sözcüklerden bazıları bulgular başlığı altında incelenmiş ve bu sözcükler incelenmiştir. Sonra istatistikler başlığı altında Grûba Xebata ya Vateyî’nin sözlüğünde tespit edilmiş olan eş anlamlı sözcükler alfabedeki sıraya göre dizilmiş olan sözcükler; en fazla eş anlamlı sözcük bulunan harf, en fazla eş anlamlısı bulunan sözcük, eş anlamlı sözcüklerin tepe değerleri, yığılma yerleri gibi istatistiki değerler ortaya çıkarılmıştır.

\subsection{Bulgular}

Aşağıda, sözlükte eş anlamlı olarak geçen ve aralarında anlam farklılıkları olan sözcükler değerlendirilmiştir. Deyimlerden ve günlük kullanımlardan örneklerle eş anlamlı sözcüklerin birbirinin yerine kullanılıp kullanılamayacağı, zıt anlamlarının da özdeş olup olmadığı ve aynı duygusal bağlamı çağrıştırıp çağrıştırmadıkları ortaya konulacaktır. Sözlükten tespit edilen eş anlamlı sözcüklerden bzı örnekler üzerinde durulacaktır. Sözcüklerin sonundaki parantezlerde yer alan $(n)$ erilliğe, $(m)$ ise dişilliğe işaret etmektedir. Zazacada doğal cinsiyetin yanı sıra, gramatikal cinsiyet de bulunmaktadır. Aynı şekilde sözcüklerin sonlarında yer alan - $e$ ise sözcügün bu eki alarak dişil hale geldiğini ifade eder. Seçilen ve incelenen örnekler rastgele seçilmiştir.

Anahtar sözcüğünün eş anlamları olarak sözlükte mifte, ziwanê kilittî, kilît, anaxtar sözcükleri sıralanmıştır (Grûba Xebata ya Vateyî, 2019). Türk Dil Kurumu tarafindan hazırlanan Türkçe Sözlük'te (2011) anahtar "kilidi açıp kapamak için kullanılan araç, açar, açkı, miftah, dil” şeklinde tanımlamıştır. Sözlükte kilit ve anahtar sözcükleri eş anlamlı olarak verilmiştir. Kilit daha çok anahtar yardımıyla açılıp kapanan aletin ismiyken, kilidi açıp kapyan alet ise anahtar olarak ifade edilir. Anahtar sözcüğü Rumca kökenliyken, kilit Farsça kökenlidir. Kilit sözcüğünün Yunanca olduğu yönünde görüşler de vardır (Kanar, 2010, 1227). Mifte olarak kaydedilmiş sözcük ise Arapça فتح sözcügünde türetilmiş ve ism-i alet olan مفتاح sözcüğüdür (Mutçalı, 2013, 686). $\mathrm{Bu}$ sözcüğün sonundaki ses düşmüştür. Söyleyişte $M i$ anaxtar a kilît akerd denilebilir ama Mi anaxtar akerd cümlesi kontekste uygun düşmemektedir. $\mathrm{Bu}$ sözcüklerden bazısı farklı dillerde de olsa eş anlamlılık ilişkisi içerisindedir. Kilit ve anahtar sözcükleri ise anlam kayması ve genişlemesiyle birbirinin yerine kullanılmaya başlanmıştır.

Bitişs sözcügünün eş anlamları olarak sözlükte qedîyayîş, xelisîyayîş, qutbîyayîş, peynîya ... ameyîş, peynîye, peynî, final sözcükleri sıralanmıştır 
(Grûba Xebata ya Vateyî, 2019). Bitiş sözcügüü "bitme işi, final" olarak tanımlanmıştır (Akalın, 2011, 363). Bu sözcüklerden qedîyayı̂ş bir işi bitirmek anlamındaki قضى sözcügünnden türetilmiştir (Mutçal1, 2013, 749). Sözcük, Zazacada qeza û qeder, qeza $\hat{u}$ bela vb. şekillerde de bulunur. Yine aynı şekilde $k a d \imath$ ve kaza sözcükleri de bu kökten türemişlerdir. Sözcügün kullanımı خلص خaygındır. Xelisîyayîş sözcüğü de aynı şekilde Arapça kökenlidir ve sözcügü ulaşmak, gelmek, kurtulmak, bitirmek, tamamlamak, sonuna gelmek vb. anlamlarına gelir (Mutçalı, 2013, 277). Aynı kökten xelas sözcüğü kurtulmak anlamında kullanılır. Bitişi ifade eden sözcüklerden qutbîyayîş de قطع sözcügünden türemiştir ve Arapça kökenlidir. $\mathrm{Bu}$ sözcük kesmek, kesip koparmak, sözünü kesmek, engellemek, bozuşmak vb. anlamlara gelir (Mutçalı, 2013, 751-752). Bitiş için eş anlamlı sözcüklerden peynî, peynîye sözcükleri ise Zazacadır. Arapçadan Zazacaya geçmiş olan sözcüklerde anlam genişlemesi meydana gelmiş ve eş anlamlı hale gelmişlerdir.

Deli sözcüğünün eş anlamları olarak sözlükte gêj, xînt, bom, xêx, delu sözcükleri sıralanmıştır (Grûba Xebata ya Vateyî, 2019). Eş anlamlı olarak kabul edilen sözcüklerden gêj sözcüğü Farsçada da كَs şeklinde ve afallamış, sersem, ahmak, aptal vb. anlamlarda kullanilır (Kanar, 2010, 1296). Ama bu sözcük anlam genişlemesi ve kayması yoluyla deli anlamında kullanılmaya başlanmıştır. Bu sözcüklerden bom ise بو şeklinde ve saf, ekilmemiş arazi anlamında kullanılır (Kanar, 2010, 315). Kullanılan sözcüklerden xêx de aynı anlamda kullanılmaktadır. Cümle içerisinde kullanıldığında No merdim bom o denildiğinde bahsedilen delilik değildir. Bu sözcüklerden delu ise aklını yitirmiş olan anlamında kullanılan Türkçe sözcüğün Zazacanın fonolojisine uyarlanmış şeklidir (Akalın, 2011, 615). Denilebilir ki eş anlamlı olarak kabul edilen xînt sözcüğü tam olarak deliyi ve deliliği ifade etmektedir. Diğer sözcükler çeşitli anlam açılarından delilikle alakalıdır. Ama tam olarak deli değildirler.

Nefes sözcügünün eş anlamları olarak sözlükte cîf, helm, boye, bîne, nefes, solix sözcükleri sıralanmıştır (Grûba Xebata ya Vateyî, 2019). Verilen sözcükler arasında nüanaslar vardır. Cîf bazen yapabilme kudreti olarak kullanılır. Örnek olarak Cîfa aye hende çinî ya cümlesinde bahsedilen kişinin yapabilme gücünün çok olmadığı ifade edilir. Helm ya da hilm doğal kokuyu ifade eder. Misale Hilmê penîrî bîyo giran cümlesinde doğal bir kokudan bahsedimektedir. Nefes, Arapçadan Türkçeye ve Zazaca gibi dillere geçmiş olan bir sözcüktür ve Arapçadaki şekli نفس can, canl1 ve beşeri ifade eder (Mutçal1, 2013, 927). Yani bir anlamda nefes almak canlılı̆̆ın işaretidir. Solix ise nefes, hava anlamında kullanılan Türkçe sözcügün Zazacanın fonolojisine uyarlanmış şeklidir (Akalın, 2011, 2135). Boye ve bîne sözcükleri Zazaca ve Kurmanccada kullanılan şekillerdir. Ez boye nêgîna derken konuşmacının kastı nefes veya koku alamamaktır. Bu anlamda her iki sözcük de nefesi karşılamakta ve nefesin eş anlamlısı olmaktadırlar. Ama bu ancak anlam genişlemesiyle meydana 
gelmektedir. Yoksa aynı sözcükler Zazaca, Kurmanccada ve Farsçada koku anlamında kullanılmaktadır (Kanar, 2010, 316). Kanar'a göre sözcük Pehlevice kökenlidir ve güzel kokuyu ifade eder. Nefes sözcügünün eş anlamlısı olarak tespit edilen sözcükler genelde bu kavramın anlam çerçevesi içerisinde değerlendirilebilir.

Romatizma sözcügünün eş anlamları olarak va, hewa, suzî, romatîzma sözcükleri sıralanmıştır (Grûba Xebata ya Vateyî, 2019). Bu sözcüklerden va ve hewa, rüzgarı ve havayı ifade etmektedir. Zazacada Va kewto çoganê mi derken kasıt bacaklara romatizmanın tesir etmesidir. Suzî ise yanma anlamına gelir ve Farsçada da aynı şekilde kullanılır (Kanar, 2010, 920). Romatizma, Türkçede kaslarda ve özellikle eklemlerde kendini gösteren ağrılı hastalıkların genel adıdır (Akalın, 2011, 1983). Yel sözcüğü Türkçede de romatizma ă̆rısını ifade eder (Akalın, 2011, 2566). Farsçada da hava, rüzgar anlamına gelen باد sözcügü iltihap anlamına da gelir (Kanar, 2010, 252-253). Kurmanccada $b a$ ketin romatizmayı ifade eden bir tabirdir. Karşılaştırılan dillerde romatizma sözcügünün eş anlamlısı olarak kullanılan sözcükler hava ve rüzgarı ifade eden kelimelerdir. Bu sözcükler anlam genişlemesi yoluyla yeni anlamlar kazanmıştır.

Süzgeç sözcügünün eş anlamları olarak parzun, sefok, suzgeç, kamos, filtre, torre sözcükleri sıralanmıştır (Grûba Xebata ya Vateyî, 2019). Süzgeç, sıvıları süzmeye yarayan araçtır (Akalın, 2011, 2193). Zazacada suzgeç olarak kullanılan sözcük Türkçeden Zazacaya geçmiştir. Filtre, Fransızcadan Türkçeye ve Zazacaya geçmiş ve süzgeç anlamına gelen bir sözcüktür (Akalın, 2011, 878). Sefok sözcügü Arapça صف_صفا kökünden türemiştir. Bu sözcük Arapçada da berrak olma, arıtmak, temiz olmak, süzmek anlamlarına gelir (Mutçalı, 2013, 174). Saf veya sef kökünden alınan bu sözcük, Zazaca -ok ekiyle beraber süzgeç anlamını kazanmıştır. Kamos ve parzun sözcükleri ise Zazacada kullanılan ve süzgeci ifade eden kelimlerdir. Torre ise ağ sözcüğünün anlam genişlemesi yoluyla kullanılmasıdır. Farklı dillerden Zazacaya uyarlanan sözcükler süzgeç sözcügünü ifade etmiştir.

Tat sözcügünün eş anlamları olarak tehm, lezet, ekil sözcükleri sıralanmıştır (Grûba Xebata ya Vateyî, 2019). Bu sözcüklerden tehm, Arapça طعözcüğünden Zazacaya geçmiştir. Tehm ya da Te'eme sözcüğ̈ tat, lezzet ve zevki ifade eder (Mutçalı, 2013, 567-568). Aynı şekilde lezet sözcüğü de لذّ sözcügünden alınmadır (Mutçalı, 2013, $\wedge r$ r). Tat sözcügünün eş anlamlıları içerisinde belki de en ilginci ekil veya ekl sözcüğüdür. Bu sözcük de Arapçadan Zazacaya geçmiştir. Ekil sözcüğ̈̈ Arapçadaki yedi anlamına gelen اكل sözcügünden Zazacaya geçmiştir (Mutçal1, 2013,37). Eklê na sa weşo denildiği zaman Bu elmanın tadı güzeldir, Bu elmanın yemesi güzeldir ifade edilmiş olur. İncelenen sözcüklerin hepsi Arapçadan alıntılanan sözcüklerdir ve hepsi de lezzeti ve tadı ifade etmektedirler. 
Uyuma sözcügünün eş anlamları olarak hewnaşîyayîş, busayîş, wutiş,

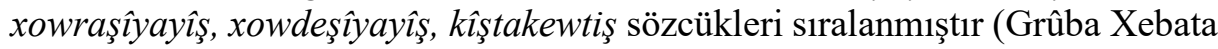
ya Vateyî, 2019). Eş anlamlı olarak tespit edilen sözcüklerin her biri uykunun farklı bir merhalesini ifade etmektedir. Örnek olarak hewnaşîyayı̂s, uykuya dalmayı ifade eder. O hewna şîyo derken uyuma kasdedilir. Busayış sözcügü esnemeyi ve uyku öncesi durumu ifade eder. Zaf hewnê aye ameyo, aya busena denildiğinde bahsedilen kişinin (dişil) esnediği ve uykusunun geldiği ifade edilir. Xowraşîyayı̧̧̂, xowdeşîyayı̂ş̧ sözcükleri ise kendinden geçmek, baylmak, uykuya dalmak anlamlarında kullanılır. Kîştakewtiş sözcüğü ise yan tarafa yatmak, uzanmak, yorgunluktan dolayı istemsizce uyumak anlamların ifade eder. $O$ hende betilîyabî ke kişta kewt denildiğinde bahsedilen kişinin yorgunluktan dolayı uykuya daldığı anlaşılır. İfade edildiği üzere uyuma sözcüğünü belirten bu sözcüklerden her biri farklı bir durumu betimler.

Vefat sözcüğünün eş anlamları olarak wefat, merg, merdiş sözcükleri sıralanmıştır (Grûba Xebata ya Vateyî, 2019). Ölmek veya vefat etmek toplumda değişik şekillerde ifade edilir: hayatı sona ermek, can vermek (gan dayene), eceli gelmek (ecele xo ameyene), vadesi yetmek (wadeyê xo temam kerdene, Allah'ın rahmetine kavuşmak (rehmet kerdene), hayata gözlerini yummak, son nefesini vermek vb. gibi. Bunlar insanlar arasında kullanılan sayg1 çerçevesindeki sözlerdir. Bir de argo, kaba sözler de vardır: gebermek (geber bîyayene), öteki dünyayı boylamak, tahtalı köyü boylamak... vb. gibi. Bu sözcükler ölmek fiiliyle aynı anlamda gibi görünse de pek sevilmeyen kişiler için daha çok kullanılır (Kocapınar, 2017, 199). Zazacada da aynı durum söz konusudur. Ey wefat kerd denildiğinde ölen kişinin sevilen birisi olduğu; $O$ merd denildiğinde genelde nötr bir durumdan bahsedildiği; $O$ geber $b \hat{\imath}$ denildiğinde ise ölen kişinin sevilmediği anlaşılır.

\section{2. İstatistikler}

Çalışmada Grûba Xebata ya Vateyî'nin hazırlamış olduğu ve son olarak 2019 yılında yayımlamış olduğu Türkçe-Zazaca sözlük temel alınmış ve bu sözlükte yer alan Zazaca eş anlamlı sözcükler tespit edilmiştir. Bu sözlükte yaklaşık olarak 490 tane eş anlamlı sözcük tespit edilmiştir. Bu sözcüklerin bazılarının 2 bazılarının ise 7 taneden daha fazla eş anlamlısı vardır. Bu sayılara göre çalışmada ortalama 2500-3000 tane eş anlamlı sözcük tespit edilmiştir. Bazı gramer kitaplarında Zazacadaki eş anlamlı sözcüklerle ilgili dökümantasyon çalışmaları yapılmıştır ama bunlar sınırlı sayıda ve teorik boyuttta değildirler. Özellikle istatistiki çalışmalar yapılmamıştır. Eş anlamlı sözcüklerin, alfabedeki hangi seslerde daha çok kümelendiklerini tespit etmek fonolojik değerlendirmeler için; her bir sözcüğün kaç tane eş anlamlısının olduğunu tespit etmek de Zazacayı dil ekonomisi açısından analiz etmek için önemlidir. Aşağıda bu sözcükler harflere göre ve eş anlamlı sözcük sayısına 
göre analiz edilmiştir. Birinci tabloda alfabede bulunan seslere göre eş anlamlı sözcük sayısı gösterilmiştir. Alfabetik sıraya göre her seste kaç tane eş anlamlı sözcük tespit edildiği grafikle gösterilmiştir. Sözlük Türkçe-Zazaca olduğu ve her Türkçe sözcüğe karşı kaç tane Zazaca sözcük olduğunu gösterildiği için, Türkçe sözcük başta yazılmıştır.

Tablo 1: Türkçe-Kirmancca (Zazaca) Sözlük'e Göre Zazacadaki Eş Anlamlı Sözcük Sayıs1

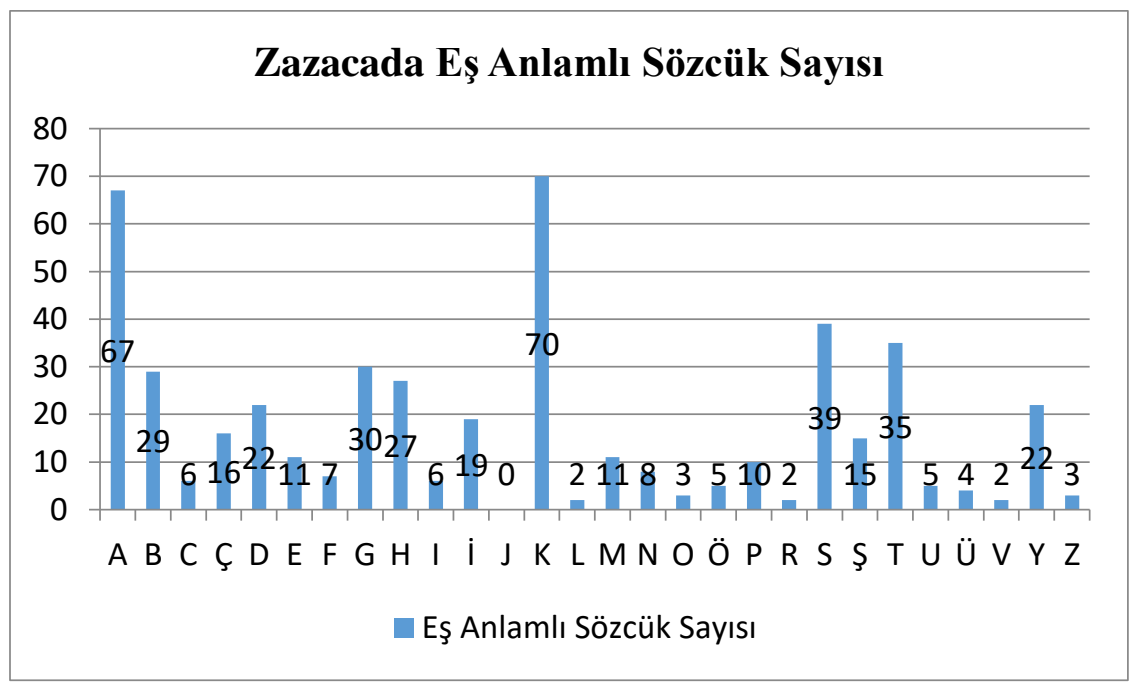

Yukarıdaki tabloya göre Zazacada en fazla eş anlamlı sözcük bulunan ses $/ \mathrm{k} / \mathrm{ve} / \mathrm{a} /$ sesleridir. Bu seslerden birinin konsonant birinin ise vokal olmas1 ilginçtir. Bu sesleri /s/, /t/ ve /g/ sesleri takip etmektedir. Ama bu sesler arasında oransal olarak ciddi bir fark vardır. Tabloya göre en az eş anlamlı sözcük bulunan sesler ise $/ \mathrm{j} /, / \mathrm{l} /, / \mathrm{r} /, / \mathrm{v} /, / \mathrm{z} /, / \mathrm{o} /{ }^{\prime}$ dur. Bu seslerden sadece bir tanesi vokal geri kalanlar ise konsonanat seslerdir. $/ \mathrm{j} /, / \mathrm{v} /, / \mathrm{z} /$, sesleri zaten az kullanilan seslerdir ama geri kalan seslerin alfabede kullanım oranı yüksektir. Burada çıkan sonuç, bu seslerin frekanslarıyla uyum göstermemektedir. Geri kalan seslerde ise birbirine yakın değerler tespit edilmiştir. Bu sesler açısından, eş anlamlı seslerin dengeli bir dağılım gösterdiği söylenebilir.

Tablo 2: Türkçe-Kirmancca (Zazaca) Sözlük'e Göre Zazacadaki Eş Anlamlı Sözcük Maddesi 


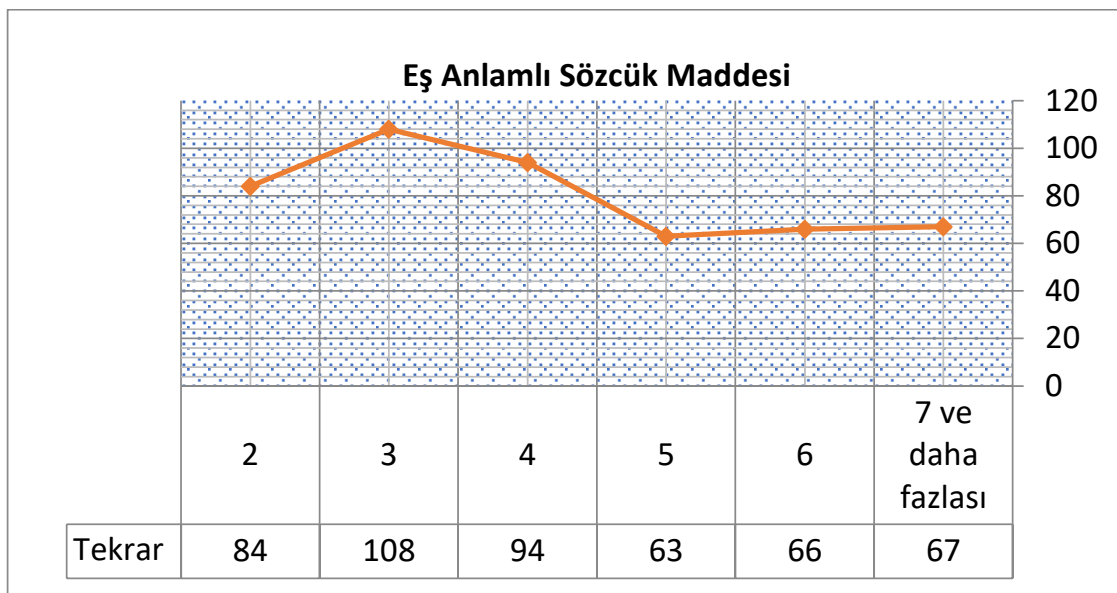

Yukarıdaki tabloda alfabedeki seslere göre dağılmış olan eş anamlı sözcüklerin maddelere göre analizi yapılmıştır. Buna göre en az 2 tane eş anlamlısı olan sözcük sayısı 84 tane, 3 tane eş anlamlısı olan sözcük 108 tane, 4 tane eş anlamlısı olan sözcük 94 tane, 5 tane eş anlamlısı olan sözcük 63 tane, 6 tane eş anlamlısı olan sözcük 66 tane, 7 tane ve üzeri eş anlamlısı olan sözcük 72 tane olarak tespit edilmiştir. Bu durumda sözlükte tespit edilen eş anlamlı sözcüklerin yarısından fazlasının 3, 4 veya 5 tane eş anlamlısı vardır. Sözlükte 7 tane ve üzeri eş anlamlısı olan sözcük sayısı da azımsanmayacak kadar çoktur. Tablodaki rakamların yüzdelik değerleri verilirse, tespit edilen eş anlamlı sözcükler içerisinde 2 tane eş anlamlısı olan sözcük sayısı 17,24\%, 3 tane eş anlamlısı olan sözcük sayısı 22,17\%, 4 tane eş anlamlısı olan sözcük sayısı $19,30 \%, 5$ tane eş anlamlısı olan sözcük sayısı 12,93\%, 6 tane eş anlamlısı olan sözcük sayısı 13,55\%, 7 tane ve üzeri eş anlamlısı olan sözcük sayısı 13,75\% oalarak hesaplanmıştır. Eş anlamlı sözcüklerin sayıca ve oranca çok olması dilin zenginliğine işaret edebileceği gibi, dilin yabancı sözcüklerden çok alıntı yaptığına da kanıt olabilir. Ama ifade edildiği üzere çalışmada yabancı sözcüklerin karşıllğı verilmiş olan sözcükler sıralanmamıştır.

\section{Sonuç}

Çalışmada Zazacada tespit edilen eş anlamlı sözcükler üzerinde durulmuştur. Zazacadaki eş anlamlı sözcükler üzerine bundan önce müstakil bir çalışma yapılmamıştır. Çalışmada yapı bakımından eş anlamlı sözcükler incelenmiş ve bu tür sözcüklerin bazı özellikleri ortaya çıkarılmıştır. Her ne kadar Arapçada eş anlamlı ve zıt anlamlı sözcükler üzerine birçok çalışma yapılmışsa da Zazacada bu konu halen yeterince çalışılmamıştır. Türkçede de aynı durum söz konusudur. Asıl olarak dilbilimcilerin tartıştıkalrı konu dilde eş anlamlı sözcüklerin olup olmadığıdır. Eş anlamlılık dilde yoruma kapı aralayan 
ve dili renklendiren bir kavramdır. Edebiyat ve sanatsal metinler için bu durum bir avantaj olarak değerlendirilebilir. Ama dinsel metinler, hukuk metinleri, uluslararası antlaşma metinleri vb. metinlerde eş anlamlılık bir dezavantaj olarak ortaya çıkmaktadır.

Zazacada eş anlamlı sözcükler yoğun ve zengin bir şekilde yer almaktadır. Yabancı dilelrden alıntılanan sözcükler eş anlamlı olarak nitelendirilmese de, süreç içerisinde bu sözcükler dildeki asli sözcüklerden birisi haline gelir ve ifade ettiği anlam bakımından diğer sözcüklerle eş anlamlılık ilișkisini kurar. Örnek olarak Türkçedeki hekim ve doktor sözcükleri arasında böyle bir anlam ilişkisi ortaya çıkmıştır. Zazacada da bu türden sözcükler vardır. Bazen aynı sözcük birden fazla sözcükle ifade edilmiştir. Bu durum yoğunluklu olarak sözlü dilin kullanılmasına, Zazaca konuşulan bölgeler arasında kültürel etkileşimin eksik olmasına, dildeki sözcükleri tespit ve dikte ettirecek bir kurumun olmamasına vb. nedenlere bağlıdır. Çalışmada Zazaca sözcüklerdeki allomorflar göz önüne alınmamıştır. Bazen sözcügün farklı görüntüleri, farklı bir sözcük olarak anlaşılabilmektedir.

Çalışmada eş anlamlı sözcüklerin, tespit edildiği kadarıyla, seslere dağ 1 lımı hem sayısal hem de grafik üzerinde gösterilmiştir. Eş anlamlı sözcükler vokal ve konsonant sesler arasında dengeli bir şekilde dağılmışlardır. Alfabede kullanım frekansları düşük olan seslerde, eş anlamlı sözcük sayısı da düşüktür. Ayrıca ikinci grafikte eş anlamlı sözcüklerin kaç tane sözcükle ifade edildiği tespit edilmiştir. Zazacada eş anlamlı olarak ifade ediilen sözcüklerin yoğunluklu olarak üç, dört ve beş tane karşılığı bulunmaktadır. Bazen bu sayı yedi ve daha üzerine de çıkabilmektedir. Eş anlamlı olarak tespit edilen sözcükler buradakilerden kesinlikle daha fazladır. İstatistiki bilgiler bu sözcükler üzerinden hesaplanmıştır. İfade edildiği üzere, eş anlamlı sözcük sayısının fazla olması Zazaların mozaik bir coğrayada yaşamasından, farklı dillerin tesiri altnda kalmasından kaynaklanmaktadır. Zazaca farklı dillerden aldığı sözcükleri kendi fonolojisine uyarlamış ve çekime uğratmıştır. Bu da sözcügün Zazacanın malı haline geldiğini göstermektedir. 


\section{Kaynakça}

Abouelnasr, Z. (2004). Eş Anlamlılık Olgusu ve Eş Anlamlı Kelimelerin Arapça Öğretimindeki Yeri. Yayımlanmamış Yüksek Lisans Tezi, Ankara: Gazi Üniversitesi Eğitim Bilimleri Enstitüsü.

Ahanov, K. (2013). Dil Biliminin Esasları. Ankara: Türk Dil Kurumu Yayınları.

Akalın, Ş. H. (2011). Türkçe Sözlük. Ankara: Türk Dil Kurumu Yayınları.

Aksan, D. (1974). "Eşanlamlılık Sorunu ve Türk Yazı Dilinin Saptanmasında Eş Anlamlılardan Yararlanma". Türkoloji Dergisi, 6/1, 1-14.

Aksan, D. (1998). Anlambilim, Anlambilim Konuları ve Türkçenin Anlambilimi. Ankara: Engin Yayınevi.

Bussmann, H. (2006). Routledge Dictionary of Language and Linguistics. London ve New York: Routledge.

Crystal, D. (2008). A Dictionary of Linguistics and Phonetics. Oxford: Blackwell.

Grûba Xebate ya Vateyî (2019).Sözlük Türkçe-Kırmancca Zazaca. Ferhengê Tirkî-Kirmanckî, İstanbul: Vate.

Hengirmen, M(2009). Dilbilgisi ve Dilbilim Terimleri Sözlüğ̈̈. Ankara: Engin Yayınevi.

İmer, K., Kocaman, A. ve Özsoy, S. (2011). Dilbilim Sözlüğ̈̈. İstanbul: Boğaziçi Üniversitesi Yayınevi.

Kanar,M. (2010). Farsça-Türkçe Sözlük. İstanbul: Say Yayınları.

Karaağaç, G. (2013). Dil Bilimi Terimleri Sözlüğü. Ankara: Türk Dil Kurumu Yayınları.

Kıran, Z., Eziler-Kıran, A. (2013). Dilbilime Giriş. Ankara: Seçkin Yayınc1lık.

Korkmaz, Z. (1992). Gramer Terimleri Sözlü̆g̈̈. Ankara: Türk Dil Kurumu Yayınları.

Malmîsanij, M. (2015). Kurmancca ile Karşılaştırmalı Kırmancca (Zazaca) Dilbilgisi. Îstanbul: Vate.

Murphy M L. (2006). "Synonymy", Encyclopedia of Language\&Linguistics, Ed. Keith Brown, Michigan.

Mustafa Sarı, “Türk Dilinde Eş Anlamlılık ve 'Sayru-Sökel' Sözleri”, Turkish Studies - International Periodical For The Languages, Literature and 
History of Turkish or Turkic Volume 7/3, Summer 2012, p. 2219-2229, Ankara-Turkey.

Mutçalı, S. (2013). Arapça-Türkçe Sözlük. İstanbul: Dağarcık.

Sert, G. (2019). "Anlam Alanı ve Anlam Ezgisi Açısından Eş Anlamlı Durum Sıfatları: "Muhtemel" ve "Olası" Örneği”. Uluslararası Türkçe Edebiyat Kültür Ë̆itim Dergisi, 8(1), 93-121.

Vardar, B. (2002). Açıklamalı Dilbilim Terimleri Sözlüğü. İstanbul: Multilingual Yayınları.

EK: Türkçe-Kirmancca (Zazaca) Sözlük’te Tespit Edilen Zazacadaki Eş Anlamlı Sözcükler

abdest: destmaj (n), awdest (n)

abla: ate $(\mathrm{m})$, atike $(\mathrm{m})$, wake $(\mathrm{m})$, waye $(\mathrm{m})$, waya pîle $(\mathrm{m})$

acayip: xam, -e; tewş, -e; temaşe, -ye; temaşa (m), ecayîb, -e; ecêb, -e; mixêr, -e; edetan ra vete, edetan ra vetî, edetan ra veta, edetan ra teber

acılık: 1) talî (m), talîye (m), talênî (m), calî (m), calîye (m) 2) tujî (m), tujîye $(\mathrm{m})$, tujênî $(\mathrm{m})$, tunî $(\mathrm{m})$, tunîye $(\mathrm{m})$, guzinî $(\mathrm{m})$, guzinîye $(\mathrm{m})$

âdemelması (gırtlak çıkıntısı) : zengilok (n), gilê qirrike (n), nêrîyê qirrike $(n)$, saya gilbe $(m)$, girêyê zuqlike (n)

adet: 1) hûmare (m) 2) tene (m), hebe (m)

ahlat: qorçe $(\mathrm{m})$, şekoke $(\mathrm{m})$, murîya koyî $(\mathrm{m})$, murîya qoqe (m)

ahmak: kav, -e, kavik, -e; xêv, -e; xêvek, -e, xêvo (n), xêx, -e; gêj, -e; gêjo (n), ehmeq, -e; avanax, -e; budela (n)

akarsu: 1) ro (n), robar (n), çem (n) 2) lay (m)

akciğer: pişike (m), qesebaya sipîye (m)

akın: hêriş (n), gale (m), galim (n)

akrep: dimpiştik (n), dimaşkil (n), aqreb (n)

alçakgönüllülük: nefsqijî (m), nefsqijîye (m), zerrîşenikî (m), mutewazîyî (m) 
I. alerji: 1) alerjî (m) 2) (kaşıntılı alerji) îre (m), xurek (n) 3) (yiyecekten olan alerji) şaplore (m)

Alevilik: elewîyîye (m), elewîyênî (m), elewîtîye (m) ; qizilbaşîye (m), qizilbaşênî $(\mathrm{m})$, qizilbaştîye $(\mathrm{m})$

alıç: simze $(m)$, sêze $(m)$, givêje $(m)$

alışma: musayîş (n), banderbîyayîş (n), banderêxodayîş (n), serkewtiş (n), xoracidayîş (n), alim (n), alimgirewtiş $n)$

altın: zerrn (n), zerd (n), altun (n)

alüvyon: lixe (m), remil (n), aluvyon (n)

amaç: 1) amanc (n), hedef (n) 2) xaye (n) 3) meqsed (n)

ambülans: ganxelasker (n), canxelasker (n), ambulanse (m)

amca: dat (n), ded (n), ap (n)

amca karısı: nacnîye (m), nacnî (m), datcinî (m), dedcinî (m), emcinî (m)

amca kızi: datkêna (m), kênapî (m), kêna apî (m)

amca oğlu: datîza (n), deza (n), lajê apî (n) (m)

an: game (m), hele (m), hing (n), linge (m), hême (m) ; vîste (m), vîstike

ana: maye $(\mathrm{m})$, mare $(\mathrm{m})$; dayîke $(\mathrm{m})$, dadî $(\mathrm{m})$

anahtar: mifte (n), ziwanê kilîtî (n), kilît (n), anaxtar (n)

anırmak: 1) zirayene, zîqayene 2) zir-zir kerdene

anız: firêze (n), xozan (n)

aniden: nişka, nişka ve ra, tavilê, taf de, xaftela, xafil de, xafila

anlamak: fehm kerdene, sere kewtene, ser şîyene, tede vetene, hiş kewtene anmak: 1) yad kerdene, zikir kerdene, zikirnayene 2) ardene vîrê xo 3) girewtene fekê xo

anne: maye $(\mathrm{m})$, mare $(\mathrm{m})$; dayîke $(\mathrm{m})$, dadî $(\mathrm{m})$

anüs çıkıntısı: zutike (m), tizike (m), sursuruk (n), turturik (n), tabut (n)

apış arası kılları: ramî (zh), tuk (n), berzik (n), keşî (zh)

apışlık: pêşe (m), keşe (m), pisa (m), piseke (m), navran (n)

ardıç: wers (n), merx (n) 
arkadaş: heval, -e; embaz, -e

asa: çogane (m), esa (m), çanqil (n), uşîre (m)

asistan: hetkar, -e; ardimkar, -e; asîstan, -e

asker: leşker, -e; esker, -e

asma-I (idam etme) : dardekerdiş (n), radareştiş (n), leqnayîş (n), aliqnayîş (n), daliqnayîş (n), îdamkerdiş (n), xeniqnayîş (n)

astrolog: estarenas, -e; astrolog, -e; munecîm, -e

aşağı: 1) cêr (n) 2) war, waro, xuwar, diwar

âşık-I: 1) aşiq, -e 2) heskerdox, -e

aşık-II (aşık kemiği) : gozeke (m), gozeka linge (m), kabe (n)

aşılama (bitki için) : lulkerdiş (n), badiroskerdiş (n)

at: estor, -e; hesp, -e; yaxte (n)

atik: çapiksuwar, -e; cansivik, -e; gansivik, -e; sivik, -e; canşenik, -e; ganşenik, -e; şît, -e; vît, -e

atkı: milpêşe $(\mathrm{m})$, kaşkole $(\mathrm{m})$, atqî $(\mathrm{m})$, atqîye $(\mathrm{m})$, dolaxe $(\mathrm{m})$

atlama (uzun atlama) : perayîş (n), çingdayîş (n), xoeştiş (n), erzîyayîş (n), çildane $(\mathrm{m})$, kildane $(\mathrm{m})$

avanak: kav, -e, kavik, -e; xêv, -e; xêvek, -e; xêvo (n), gêj, -e; gêjo (n), ehmeq, -e; avanax, -e; budela (n)

avare: eware (n), ewara (m), sûtal, -e; gêrende, -ye; serberadaye (n), serberadayîye (m), serberadayî (m) ; selexane, -ye

aya: miste (m), sala destî (m), sale (m), kefe (m)

ayak: 1) linge (m), pa (n) 2) $(30,5 \mathrm{~cm})$ pa (n), fût (n)

ayakkabı: sol (n), pêlav (n), yemenî (n), postal (n)

ayakkabıcı-I (yapan ya da satan) : koşkar, -e; solderz, -e, postalçî, -ye

ayarlamak: kok kerdene, eyar kerdene

ayaz: huşka (n), wişka (n), qija (n)

aybaşı (kadın için) : bêdestmajîye (m), bêdestmajî (m), bênimajî (m), çekî (zh), serê aşme (n), hayîz (n)

ayçiçeği: verroj (n), verrojik (n), vila rojî (m), vilika rojî (m), gula ververojî $(\mathrm{m})$, gogebaxan $(\mathrm{n})$ 
ayıklamak: weçînitene, weçînayene, vîjnayene

ayrılmak: abirîyayene, rabirîyayene, aqitîyayene, cîyabîyene (n), cêbîyene, cêrabîyene, cêravejîyayene, cêservejîyayene, cêserbîyene, cêserkewtene

ayva: beye $(\mathrm{m})$, heywa $(\mathrm{m})$

az: tay, -e; tîkê; şenik, -e; kêmî

azami: tewr zaf, tewr bol, tewr zîyade, tewr vêşî; zafê zafan, bolê bolan, zîyadeyê zîyadeyan, vêşê vêşan, ezamî

baca: lojine $(\mathrm{m})$, pixêrî $(\mathrm{m})$, tifike $(\mathrm{m})$

bacak: çaq (n), paq (n), pale (m), şeqe (m)

bă̆-I: rez (n), bax (n)

bağımsız: xoser, -e; mustaqîl, -e

bahtiyar: bextîyar, -e; bextewer, -e; zerrîweș, -e; mesud, -e

baldır: çîp (m), peyîke (m), saq (n)

balmumu: şema (m), momî (m), momîya hingimênî (m)

balta (büyük balta) : tuwerzîn (n), tore (n), balte (n)

barışma: aştbîyayîş (n), pêameyîş (n), werêameyîş̧ (n)

baston: çogane $(\mathrm{m})$, çanqil (n), gopale $(\mathrm{m})$, bastone $(\mathrm{m})$

basur: tawin (n), masîla (m), basur (n)

bayıltma: xeriqnayîş (n), xewirnayîş (n), xemînayîş (n)

baykuş: kund (n), bum (n), puyo kor (n)

beden: beden (n), wucud (n), govde (n)

bızır: zîlik (n), çîlik (n), gilik (n), nîçik (n), nerî (n), surik (n)

biber: îsot (n), bîber (n), bacik (n)

bilmece: çibenok (n), mertal (n)

bilye: xare (m), gule (n), cînciq (n), bîlya (m)

bitiş: 1) qedîyayîş (n), xelisîyayîş (n), qutbîyayîş (n), peynîya ... ameyîş 2) peynîye $(\mathrm{m})$, peynî $(\mathrm{m})$, fînal $(\mathrm{n})$ 
boğaz: 1) qirrike (m), gilbe (m), gule (m), boxaz (n) 2) neqeb (n), boxaz (n)

boș: veng, -e; tal, -e; bos, -e

böbrek: velke (m), gurçike (m)

böcek: lulik (n), kêze (m), kêzike (m), marik (n)

budak: qît (n), qîtik (n), toke (m), girçike (n)

bölmek: pare kerdene, teqsîm kerdene

bulanık: lêl, -e; mijxelî, -ye

bulgur: belxur (n), savar (n)

burun: pirnike $(m)$, zincî (m), kepuge $(m)$, vinî (m)

büyütmek: 1) gird kerdene, girs kerdene, xişn kerdene 2) pîl kerdene

C

can: gan (n), can (n)

ceht: lebate (m), xîret (n), cehd (n)

ceket: 1) çakêt (n), şak (n), setre (n), çoxe (n), kurtik (n) 2) şapik (n)

(yünden örülme, boyu ve kolları kısa ceket) 3) (kadın için) qol (n), qolik (n)

cımbız: mûçîne (m), qisqance (m), cimbize (m)

cırcırböceği: temuz, -e; çîrçîrik (n), qijqijok, -e

cimri: çimteng, -e; pexîl, -e

\section{Ç}

çaba: lebate (m), xîret (n), cehd (n)

çadır: çadire $(\mathrm{m})$, xeyme $(\mathrm{m})$, xivête $(\mathrm{m})$, kone $(\mathrm{m})$

çakıl: xîç (n), zigar (n), boxar (n), çaxil (n)

çalı: leme (m), leye (m), heje (m), hejike (m)

çalıştırma: xebitnayîş (n), gurenayîş (n), şuxulnayîş (n)

çekirge: kulî (n), mele (n), peqpeqok (n), çekçeko (n)

çelişki: nakokî (m), tenaquz (n), tezad (n)

çelmik: qisle (n), qislik (n), xiz (n), zingire (n)

çevre: 1) dorûver (n), derûdor (n), dorme (n), derûdorme (n), çorşme (n), norî-orî 2) cugeh (n) 
çıban: sûrbine (m), kunêre (m), kergane (m), kule (m)

çırılçıplak: rutûrepal, -e; rut-repal, -e; zit-bulit, -e; zilut, -e; bane û banqilîz, -e; zit-bana (m), zit-bane (n) ; virtûviran, -e; çîp-çîplax, -e xirik (n)

çırpı: qirçe $(m)$, qirçike $(m)$, qurçine $(m)$, peje $(m)$, pejike $(m)$, çirpî $(m)$,

çirkin: bexûd, -e; qefçil, -e; pîs, -e; bêrûçik, -e

çivi: mix (n), bismar (n)

çocuk: gede (n), geda (m) ; zak (n), zaka (m) ; leyîr, -e; doman, -e; qeçek, -e; qic, -e; put, -e; tut, -e; lorik, -e; eyel, -e; mindal, -e

çok: zaf, -e; bol, -e; zîyade, gelek, xeylê, vêŝî

damar: damare $(\mathrm{m})$, reya $(\mathrm{m})$

dansör: kayker (n), dansor (n), reqas (n)

dansöz: kaykere $(\mathrm{m})$, dansoze $(\mathrm{m})$, reqase $(\mathrm{m})$

dargınlık: 1) herid (n), cigir (n), hêrs (n) 2) miradîyayeyî (m), miradîyayeyîye $(\mathrm{m})$, celûdîyayeyî $(\mathrm{m})$, celûdîyayeyîye $(\mathrm{m})$

darı: gilgil (n), korek (n)

dede: kal (n), kalik (n), bawkal (n), pîrik (n), bapîr (n), pîrbab (n), pîrbav (n)

değer: rûmet (n), erje (m) (mat), qîymet (n)

deli: gêj, -e; xînt, -e; bom, -e; xêx, -e; delu, -ye

delik: qule (m), lane $\mathrm{m})$

deniz: derya (n), behr (n), dengiz (n)

deste: 1) (kıllı̧ vb. için) deste (n), destik (n), dim (n), qebza (m), qevde (m) 2) qevde (m)

dikkat: bale (m), dîqet (n) ; baldarî (m)

dilsiz: 1) bêziwan, -e 2) lal, -e

direk: kêran (n), şirît (n) ; maxe (m), pirde (m), çuwe (n), cisir (n) ; dîrege (m)

domates: firingî $(m)$, şamike $(m)$, lolike $(m)$, tomatêse $(m)$, balcana sûre $(\mathrm{m})$, balcane $(\mathrm{m})$ 
donma: cemidîyayîş (n), qeşagirewtiş (n), qerisîyayîş (n), qersegirewtiş (n), qersedekewtiş (n), qefilîyayîş (n)

doruk: tîtik (n), nîçik (n), gil (n), tap (n), tiltilik (n)

dost: 1) birak, -e, destebira, -ye 2) dost, -e 3) yar, -e

dönemeç: hoke (m), çivir (n), vîraj (n), fetiloke (m)

duvar: 1) dês (n), dîwar (n) 2) bende (m)

düz: rast, -e; duz, -e

düzen: 1) nîzam (n) 2) pergal (n), sîstem (n)

\section{$\mathbf{E}$}

eczacı: darukar, -e; dermankar, -e

egzama: miloçike (m), meflonî (m), meyasîr (n), egzama (m)

ek: pabeste (n), îlawe (n)

elbet: bêguman, bêşik, helbet, tabî

elbise: kinc (n), cile (m), çina (n), çek (n), pote (m), girrêş (n), lîbas (n)

emek: kede (m), rence $(m)$, emeg $(n)$

emekçi: kedkar, -e; rencber, -e; emegdar, -e; zehmetkêş, -e

emzik: 1) mustik (n), hingilik (n), emzik (n) 2) lewtik (n)

enik: kirta (m), kirte (n) ; cewrik, -e; kudik (n), kudî, -ye; kudikê kutikî (n) ; çêlikê kutikî (n), leyîrê kutikî (n), leyrekê kutikî (n)

erbezi: gun (n), hak (n), hêlik (n), herz (n), bati (n)

etraf: dorûver (n), derûdor (n), dorme (n), derûdorme (n), çorşme (n), norîorî

\section{F}

fayda: $\operatorname{kar}(\mathrm{n})$, feyde (n)

felaket: bêtere $(\mathrm{m})$, bobelate $(\mathrm{m})$, felakete $(\mathrm{m})$, xafile $(\mathrm{m})$, musîbete $(\mathrm{m})$, xezeb (n)

fena: xirab, -e; nebaş, -e

fermuar: rêzile (m), zincîre (m), zirze (n), fermuar (n)

filtre: parzun (n), suzgeç (n), sefok (n), fîltre (n)

fiske: çirtike (m), çirpike (m), çîpike (m), çiftike (m), nîrçike (m) 
folklor: şarnasî (m), şarnasîye (m), folklor (n)

G

gafil: 1) bêhayî, -ye; bêxeber, -e 2) nezan, -e

garaz: xerez (n), kîn (n), rike (m)

geç: berey (n), erey (n), dereng (n)

geçerli: vîyartbar, -e; muteber, -e; carî, -ye

geleme: bure (n), beyar (n)

gelenek: urf û adet, adet û tore, tradîsyon (n)

gelişim: xurtbîyayîş (n), averşîyayîş (n), raverşîyayîş (n)

gençlik: 1) ciwanî $(\mathrm{m})$, ciwanîye $(\mathrm{m})$, gencî $(\mathrm{m})$, gencîye $(\mathrm{m})$, gencênî $(\mathrm{m})$ 2) (delikanlılık) xortîye $(\mathrm{m})$, xortî $(\mathrm{m})$, xortanîye $(\mathrm{m})$, xortanî $(\mathrm{m})$, rihalî $(\mathrm{m})$, rihalîye (m) 3) cahîlî $(\mathrm{m})$, cahîlîye $(\mathrm{m})$

genel: pêroyî, hemeyî, umûmî

genişlik: 1) hîrayîye (m), hîrayî (m), hîratî (m) 2) verinîye (m) 3) panîye (m), panî (m)

gerçek: 1) rast, -e; heqîqete $(\mathrm{m})$ 2) rastîye $(\mathrm{m})$, rastî (m) 3) rastikên, -e; heqîqî, -ye

gerdel: elbe (m), elbike (m), kulenge (m)

geveze: wazan, -e; fekbaz, -e; fekwazan, -e; fekfuzul, -e; vîraca (m), vîrace $(n)$; çenebaz, -e; geveza (m), gevezîye (m), geveze (n) ; qalezaf, -e; leqleqo (n)

gicırdatma: qirçnayîş (n), çîiknayîş (n)

gizli: nimite $(\mathrm{n})$, nimita $(\mathrm{m})$, nimitîye $(\mathrm{m})$, nimitî $(\mathrm{m})$; mîyanî, pinanî, dizdênî, batin (n)

göbek: 1) nak (n) 2) meşke (m), xaşîya vêrî (m) 3) (mecazen, göbek hizası) mîye (m), mûndî (m)

göç: barkerdiş (n), wenayîş (n), koç (n), koçkerdiş (n)

gölge: sîye $(m)$, sersî $(m)$, versî $(m)$, sîdare $(m)$

gömlek: paç (n), qolike (m), îşlig (n), qemîs (n), gomleg (n)

gömme: wedaritiş $(n)$, binerdkerdiş (n), temernayîş (n)

görüş: 1) ray (m) 2) dîyayîş (n), vînayîş (n) 
göt: qine $(\mathrm{m})$, peynî $(\mathrm{m})$, peynîye $(\mathrm{m})$

gözbebeği: bîbike (m), bîbika çimî (m), lîlike (m)

gözetim: 1) ewnîyayîş (n), qayîtkerdiş (n) 2) seveknayîş (n), muhafeze (n), pawitiş (n), miqatkerdiş (n), hemetkerdiş (n) 3) nezaret (n)

gözetme: ewnîyayîş (n), qayîtkerdiş (n), miqatbîyayîş (n)

gulyabani: xeybane (n), çaqilçîman (n), qetrepoz (n), mêrdeyê şewe (n), zurvanê pesewe (n) gübre: 1) zibil (n), ziblûzebale (m), sil (n) 2) (keçi ve koyun gübresi) pişke (m) 3) (kimyasal gübre) gubre (n)

güç: 1) hêz (n), qewet (n) 2) zor, -e; zehmet, -e; çetin, -e

gürültü: hermele (n), welwele (n), haylemin (n), vengane (n), qelebalix (n), heşamete (m)

güvercin: borane (m), kurkurike (m), kevok, -e; gogerçîne (m)

güzel: 1) rind, -e; rindek, -e; xasek, -e; 2) semt, -e

\section{$\mathbf{H}$}

haber: xebere (m), hayî (m), agahî (m), vengûvaj (n)

hafif: sivik, -e; şenik, -e; xefîf, -e

hâlâ: hîna, hema, daha

halat: kendir (n), xelat (n)

halay: 1) govende (m) 2) (serçe parmakla tutuşarak oynanan halay) nazo $(\mathrm{n})$, qilance $(\mathrm{m})$, qilancike $(\mathrm{m})$, qilîçe $(\mathrm{m})$, mîme $(\mathrm{m})$, delîlo (n), dûzo (n), sivikî (m), keşane (m) 3) çepikî (zh) 4) çepkî (n) 5) veracê (n) 6) şîrbonî (m)

ham-I: 1) xam, -e; 2) xawiz, -e; xag, -e 3) kal, -e 4) nêderesaya (m), nêderesayîye $(\mathrm{m})$, nêderesaye $(\mathrm{n})$; nêresaya $(\mathrm{m})$, nêresayîye $(\mathrm{m})$, nêresaye $(\mathrm{n})$; nêresta $(m)$, nêrestîye $(m)$, nêreste $(n)$

hareket: hereket (n), liv (n), lebat (n), tevger (n)

harp: ceng (n), herb (n)

hastane: xestexane (n), nêweşxane (n)

haşlamak: kemidnayene, xaşênayene, şeliqnayene

hatmi: hîro (n), dîkê orisî (n)

haya (erkeklik bezi) : gun (n), hak (n), hêlik (n), herz (n), bati (n)

hekim: doktor, -e; hekîm, -e 
hengâme: babagundî $(m)$, qergundî $(m)$, welwele $(n)$, haylemin $(n)$, hayûhuy $(\mathrm{n})$, hay-huy $(\mathrm{n})$, teqûreqe $(\mathrm{m})$, teq-reqe $(\mathrm{m})$, hermele $(\mathrm{n})$, şemate $(\mathrm{n})$, helahela (m)

heykel: qame (m), heykel (n), peyker (n)

hız: lezîye (m), lezî (m), suret (n)

hızma: pozmik (n), xizme (m), penesik (n)

hile: 1) hîle (n), oyn (n) 2) xilt (n)

hindi: 1) kerga misrî (m), kerga şamî (m), hulî, qulî, pîpî, qaze (m), culixe (m) 2) dîkê misrî (n), dîkê qaze (n) 3) elok, -e; elelo, -ye

hissetme: teyvetiş $(n)$, tedevetiş $(n)$, tedeteyvetiş $(n)$, povetiş $(n)$, hîskerdiş (n), ferqkerdiş $(\mathrm{n})$

horoz: dîk (n), keleşêr (n), heke (n)

hovarda: xwarde (m), tolaz (n), çimteber (n)

hurda: xurde (n), qaf (n), qafek (n), qaflet (n)

huni: mastêr (n), kovik (n), xunî (n) xas, -e

hususi: taybetî, -ye; arizî, -ye; xususî, -ye; kesî, -ye; şexsî, -ye; zatî, -ye; 185

huzur: 1) aramî (m), aramîya zerrî (m), huzur (n) 2) rîqal (n), ver (n), huzur (n)

hüthüt: dîksilêman (n), hophopik (n), dûdû (n)

ılıca: germike (m), germawe (m)

llık: şîrgerm, -e; serdgerm, -e; vilnerm, -e; nerm, -e

Irgat: êrxat, -e; pale (n), pala (m) ; rencber, -e

II. 1sı: $\operatorname{tanî}(m)$, germ (n) ; germîye $(m)$, germî $(m)$, germênî $(m)$

Işık: roşn (n), roşt (n) ; roşna $(m)$, roştî $(m)$; şewq (n), şewq û şemale, şewle (n), nur (n)

Izgara: caxike (m), izxara (m)

ibibik kuşu: dîksilêman (n), hophopik (n), dûdû (n) 
ibik: kilaweke (m), pilike (m), kulike (m), fese (m)

iblis: îblîs (n), şeytan, -e

için: seba, seba ke, semedê ..., semedo ke; qandê, qando ke, qandê ... rê

içtimai: sosyal, cematkî, komelkî

idareci: îdarekar, -e; sermîyan, -e

idrar: mîze (m), destawe (m), destawa şenike (m)

iflas: topeeştiş (n), îflas (n)

III. iğ: rêşta (m), rêstike $\mathrm{m})$, taşî (m)

il: wîlayet (n), şaristan (n), bajar (n)

ilah: îlah (n), Homa (n), Ellah (n), Olî (n), Heq (n), Reb (n), Rebî (n), Comerd (n)

iman: bawerîye (m), bawerî (m), îman (n)

inat: 1) rike (m), serehuşkî (m), serehuşkîye (m), înad (n), eks (n

incelik: barîyî $(\mathrm{m})$, barîyîye $(\mathrm{m})$, barîyênî $(\mathrm{m})$, barîkênî $(\mathrm{m})$, tenikî $(\mathrm{m})$, tenikîye $(\mathrm{m})$, tenikênî $(\mathrm{m})$, ziravî $(\mathrm{m})$, ziravîye $(\mathrm{m})$, kîbarî $(\mathrm{m})$, kîbarîye $(\mathrm{m})$

incik: çîp (m), peyîke (m), saq (n)

işçi: karker, -e; xebatkar,-e; pala (m), pale (n) ; mişag, -e; êrxat, -e; rencber, -e; emela (m), emele (n)

işitme: eşnawitiş (n), hesnayîş (n)

işleme: 1) nejir (n), newir (n), neqiş (n), xerc (n) 2) (işlemek eylemi) nejirnayîş $(n)$, newirnayîş $(n)$, neqişnayîş $(n)$, xerckerdiş $(n)$

izleme: 1) taqîbkerdiş (n), dimaşîyayîş (n) 2) ewnîyayîş (n), nîyadayîş (n), temaşekerdiş (n), qayîtkerdiş (n), seyrkerdiş (n)

\section{$\mathbf{K}$}

kabak: kundire (m), kuy (m) ; cacixe (m)

kabakulak: algoşe (n), belegoş (n), xîyarek (n)

kabuk: patu (n), poste (n), qaş (n), qaşik (n), qaşil n), tole (n), tolik (n), qafik (n), qalik (n), pur (n), purtik (n), telaşe (n)

kaburga: parsû $(\mathrm{m})$, qabirxa $(\mathrm{m})$, caxe $(\mathrm{m})$

kabza: deste (n), destik (n), dim (n), qebza (m), qevde (m)

kafile: qefle (n), cerge (m), ref (n), gilbe (n) 
kahvaltı (sabah yemeği) : 1) arayî (m) 2) sêpare (n)

kâkül: biske (m), şehbik (n), poçax (n), pulik (n)

kalabalık: qelebalix (n), sixlet (n)

kalça: qineste (n), kule (n), qorrik (n)

kaldıraç: 1) (demirden olanı) manîla (m), mîl (n), nîk (n) 2) (ağaçtan olan1) qerase (n) 3) berzker

kale: dize (m), kela (m)

kar: vewre $(\mathrm{m})$, werfe $(\mathrm{m})$

karaciğer: cîgere (m), qeseba (m), kezebe (m), qesebaya sîyaye (m)

karasinek: mêse $(\mathrm{m})$, vizike $(\mathrm{m})$

karga: qijike (m), qela $(\mathrm{m})$, qirawile $(\mathrm{m})$, qerpelase $(\mathrm{m})$

karış: vîzoye $(\mathrm{m})$, vîncewe $(\mathrm{m})$, boste $(\mathrm{m})$

karpuz: zebeşe (m), hindî (m), qerpuze (m), buestûn (m)

kat: 1) qat (n), tebeq (n), qanat (n)

katır: qantir (n), hesterî (n)

katil: mêrkuj, -e; qetilkar, -e; kiştox, -e; qatîl, -e (n)

kav (yılan gömleği) : vere (m), vera marî (m), pirênê marî (m), kajê marî

kavak: sipîdare $(\mathrm{m})$, dehlêre $(\mathrm{m})$, hewrêre $(\mathrm{m})$, qewaxe $(\mathrm{m})$, qewaxêre $(\mathrm{m})$

kavun: beşîla (m), qawune (m)

kaya: zinar (n), çengel (n), kerre (n), kemer (n), tehran (n), sî (m)

kaygı: endîşe (m), fikar (n), qesawet (n), qaxû (n)

kaynatma: girênayîş (n), keledayîş (n), kelefîştiş (n), kelenayîş (n)

kazık: pîj (n), pîjik (n), mîyîn (n), sing (n), gulç (n), gulçan (n), erdeş (n), pist (n)

kekemelik: ziwangiranîye (m), ziwangiranî (m), lalekîye (m), kekejîye (m) ; lalûtî (m), lalî (m), lalîye (m), kukîye $(\mathrm{m})$, niqîye $(\mathrm{m})$, ziwandeginayeyî (m)

kekik: anûx (n), cehtire (n) 
IV. kel: keçel, -e; gurrî, -ye; kirr, -e

kelle-paça: serûpa (n), serûxaşî (zh), xaşî (zh), kelpaçe (n), kelle (n)

kene: kerje (n), kerjik (n), gene (n), qijne (n), qijnik (n), qirnîk (n)

kepçe: kondêz (n), çemçe (n), çemçik (n), patik (n), gepçe (n)

kez: rey $(\mathrm{m})$, fine $(\mathrm{m})$, hewe $(\mathrm{m})$, gilange $(\mathrm{m})$, donime $(\mathrm{m})$, derbe $(\mathrm{m})$, şope $(\mathrm{m})$, qor (n), defa (m), gêyîm (n), dore (m), nofe (m), neqile (m)

kılıç: şimşêr (n), kalme (n), gord (n), şûr (n)

kınalı: hineyin, -e; hinekerda (m), hinekerdîye (m), hinekerde (n)

kıră̆ı: xusk (n), qiş (n), qerawî (m), qir (n)

kırıntı: ferik (n), hurdî (n), pişrûg (n)

kısrak: mahîne $(\mathrm{m})$, estore $(\mathrm{m})$, hespe $(\mathrm{m})$

kıtlık: xela (m), xizlixîye $(\mathrm{m})$

kıvılcım: çîk (n), çeq (n), çiqlik (n), gizgarik (n)

kıvrak (başörtü) : mexmele (m), temezî (m), temezîye $(\mathrm{m})$, dolbende $(\mathrm{m})$

kıvrım: çiqir (n), tadîyaye (n)

kıyafet: belg (n), cilûbelg (n), bedl (n), qilix (n), kisvet (n)

kıymet: erje (m), rûmet (n), qîymet (n)

kir: lêm (n), lêş (n), qilêr (n), gemare (m), qirêj (n)

klitoris: zîlik (n), çîlik (n), gilik (n), nîçik (n), nerî (n), surik (n)

koku: boye (m), bîne (m), helm (m)

komisyon: 1) (altkurul) komîsyon (n) 2) komîsyon (n), sîmsarîye (m), delalîye (m)

komşu: embiryan, -e; cîran, -e

konuşma: qiseykerdiş (n), qalîkerdiş (n), xeberîdayîş (n), mijûlîyayîş (n)

koparma: visnayîş (n), qerifnayîş (n), tirakerdiş (n), cirakerdiş (n), cikerdiş (n)

kova: sitil (n), hilke (n), beroş (n), qove (n)

V. koyak: newale $(\mathrm{m})$, dole $(\mathrm{m})$, gelîye $(\mathrm{m})$, gelî $(\mathrm{m})$, cêvî $(\mathrm{m})$

kök: reya (m), ristim (n), rîștele (n), rîç (n), rîçik (n), pence (n), pencik (n), qirm (n), helq (n), kok (n) (mat) 
köz: çêle (n), bizote (n)

kucak: 1) verike $(m)$, verare $(m)$, verardî $(m)$, virane $(m)$, hemêze $(m)$ 2) (bir kucak odun vb.) verare (m), verardî (m) 3) keșe (m)

kurbağa: beq (n), qirîncele (n)

kurgu: 1) mûnite (n), pêarde (n, sn), viraşte (n), werêarde (n, sn) 2) montaj (n, sn)

kuru: 1) ziwa, -ye 2) huşk, -e

kutlama: pîrozkerdiş (n), fîrazkerdiş (n), bimbarekkerdiş (n)

kuvvet: hêz (n), qewet (n)

kuzgun: kelax, -e; qerzax (n), qirawule (m), cayîg (n)

kuzu: verek, -e; kavir, -e

küçükdil: ziwanik (n), ziwano qij (n), ziwano qît (n), belik (n)

küf: kufike (m), kufe (m), kançik (n)

küfe: sele (m), qufa (m)

küstürme: heridnayîş (n), cigirnayîş (n), miradnayîş (n), celûdnayîş (n), qehirnayîş (n), hêrskerdiş (n)

laf: qisa (m), qesa (m), qale (m)

lapa: lepawe $(\mathrm{m})$, lepe $(\mathrm{m})$

mahsul: mehsul (n), ber (n)

meğer: mevaje ke, ti mevaje ke, ti nêvanî ke, ti nêvana ke, oxmo, oxro, reyna ke, meke

meme: 1) memik (n), çiçik (n), çije (n) 2) (hayvan için) guwan (n), guhan (n) 2) hengile (m)

meni: awî (m), sperma (m), toximek (n)

merdiven: nêrdîwane $(\mathrm{m})$, derenca $(\mathrm{m})$

mevsim: demserre (m), mewsim (n)

mezar: gor $(n)$, tirbe $(m)$, meqbere $(m)$, mezele $(m)$, qebre $(m)$

mısır: lazut (n), misrî (n), gilgil (n) 
muallim: mamosta $(\mathrm{m}, \mathrm{n})$, malim, -e

mutlu: bextîyar, -e; bextewer, -e; zerrîweş, -e; mesud, -e

mühlet: muhlet (n), wade (n)

\section{$\mathbf{N}$}

nasır: deq (n), cedew (n), nasir (n)

nazar: çim (n), çimênî (m), nefes (n), nezer (n)

neden: 1) semed (n), sebeb (n) 2) çira, çayê, çinayî ra

nefes: cîf (n), helm (n), boye (m), bîne (m), nefes (n), solix (n)

nehir: ro (n), robar (n), çem (n)

nem: tên (n), rewa (n), nekme (n), wit (n), nem (n), rutubet (n)

neşe: şayî (m), şayîye (m), keyf (n), keyfweşî (m), keyfweşîye (m), keyfûşayî (m), şênayî (m), şênî (m), şênîye (m)

nine: pîrike (m), dapîre (m), dêke (m)

$\mathbf{O}$

odun: îzime (m), kolî (n)

ortak: 1) hempar, -e; pardar, -e; hîsedar, -e; nêmedar, -e; şirîk, -e; ortax, -

$\mathrm{e}$

ovma: vilênayîş (n), mîştdayîş (n), feriknayîş (n)

Ö

öğle: teştare (n), peroj (n), nêmroje (m), dihîre (m), hele (m)

öğrenci: wendekar, -e; telebe (n), teleba (m) ; suxte (n), suxta (m) ; şagird, $-\mathrm{e}$

örnek: nimûne $(\mathrm{m})$, mîsale $(\mathrm{m})$

öte: wet (n), wever (n) ; bover (n) ; ohet (n), ohêm (n)

özellik: taybetmendîye (m), taybetmendî (m), xususîyet (n), xasîyet (n)

$\mathbf{P}$

palto: saqo (n), palto (n)

pantolon: şayaxî (zh), pantolî (zh), şapikî (zh)

papağan: tûtî, -ye; papaxan, -e

patates: kartole $(\mathrm{m})$, patatîze $(\mathrm{m})$ 
pekmez: mot (n), rib (n), dims (n), helawe (m), aqît (n), bekmez (n)

pencere: pencera $(\mathrm{m})$, paca $(\mathrm{m})$, çarçîba $(\mathrm{m})$

penis: 1) kir (n), xir (n) 2) mîzî (n), bêname (n), hacet (n), setar (n)

perişan: 1) perîşan, -e 2) pergende (n), pergenda (m) 3) şerpize (n), şerpiza (m) 4) mişeqet, -e 5) mizmehal, -e

pürüz: giriz (n), guriz (n), zivir (n), xirtik (n)

püskül: piskile (m), şonpole (m), gulik (n), vilik (n)

\section{$\mathbf{R}$}

romatizma: va (n), hewa (n), suzî (n), romatîzma (n)

rüşvet: wer (n), bertîl (n), rişwet (n)

sabah: nimaj (n), şodir (n), şewdir (n), sipêde (n), siba (n)

sabır: sebir $(\mathrm{n})$, tebat $(\mathrm{n})$

sacayağı: dêwezan (n), dêzlig (n), xaçirgan (n)

saçak-I: siving (n), sifirne (n)

saf: 1) (kişi için) sax, -e; saxek, -e; saf, -e; safek, -e; kav, -e; kavik, -e; xêx, -e 2) (nesne için) xas, -e; xalis, -e

sağırlık: kerrîye $(m)$, kerrî (m), goşgiranîye (m), goşgiranî (m)

sahil: qerax (n), kenare (n), ver (n), kobe (n)

sahur: paşîve (m), suhur (n)

sakın: nêbo, zînhar, saqin

sakız: vînce (n), qanik (n), benîş̧ (n)

sakin: 1) vindeta (m), vindetîye (m), vindete (n) 2) sakin, -e 3) mendox, e; roniştox, -e

saklama: wedaritiş (n) (TE), wedardayîş (n), wedarnayîş (n) ; nimitiş (n), hewadayîş (n), hewanayîş (n)

saklambaç (oyunu) : pîrkeçel (n), pîrike (m), nimitike (m), nimitikkay (n), kukulîku (n), kukulî (n), pilolo (n)

saldırı: hêriş (n), gale (m), galim (n)

salya: gilêze (m), şorike (m), malêze $(\mathrm{m})$, gewele $(\mathrm{m})$ 
salyangoz: şeytanok (n), korbilîyes (n), guvelik (n)

saygı: rêz (n), hurmet (n), îhtîram (n)

sebze: sewzî (n), zerzewat (n), tarrûtur (n)

sevgi: 1) heskerdiş (n) 2) sînayîş (n) 3) hes (n)

seviye: duşt (n), darax (n), sewîye (m), tabî (n)

sevme: 1) sînayîş (n), sînitiş (n) 2) heskerdiş (n) 3) zerrîdekewtiş (n), zerrîcikewtiş (n), zerrîdevistiş (n), zerrîcifîștiş (n), zerrîpiranayîş (n), zerrîcikerdiş (n)

seyahat: 1) raywanîye $(m)$, rêwîyîye $(m)$, rêwîtî (m) 2) gêrayîş (n), fetilîyayîş (n)

sırf: tena, sirf, sirf-safî, saf, xalis, binra

sirık: rewte $(\mathrm{m})$, martage $(\mathrm{m})$

sırt: piştî (m), qorrik (n)

sızı: jan (n), tîre (m), suzî (n)

sızıntı (sızan şey) : 1) rêj (n), cunit (n), çuliz (n), rêjîyaye (n), (çîyo) pêşîyaye (n) 2) (çîyo) rodaye (n)

sicim: ta (n), bend (n)

sidik: mîze (m), destawe (m), destawa şenike (m)

siğil: birke $(m)$, balûge $(m)$, sîngile $(m)$

sivrisinek: melşe (n), kermêşe (m), kulinge (m), vizik (n), pînge (m)

sokak: kuçe (n), ziqaq (n)

soluk: cîf (n), helm (n), boye (m), bîne (m), nefes (n), solix (n)

son: 1) peynîye (m), peynî (m) 2) peyên, -e 3) berko (n

sorun: mesele (n), perse (m), problem (n)

soytarl: qeşmer, -e; soterî, -ye

sümük: çilane (m), çilme (m), çil (n), lîke (m), xirnike (m), pilxe (m), zux (n)

süs: tît (n), tîtik (n), xeml (n), zîynet (n)

süzgeç: 1) parzun (n), sefok (n), suzgeç (n), kamos (n), fîltre (n) torre (m) 
şafak: sipêde (n), dosere (n), şefeq (n), serê şodirî (n), serê şewdirî (n), fecir (n)

şaka: 1) heneke (m), yarî (m), yarenîye $(m)$, yarenî (m), kuşat (n), kurata (m), lexî (zh) 2) qestî (m) (m)

şakayık: şavile (m), heşvile (m), heşvilike (m), vilheşike (m), gulheşe

şans: bext (n), siûd (n), şans (n), talih (n)

şarkı: lawike (m), kilame (m), deyîre (m)

şeftali: xewxe (m), şeftalîye (m), pirçikine (m)

şekil: 1) form (n), şekil (n), toşe (n), tuleg (n) 2) suret (n) 3) dilq (n)

şemsiye: sîwane (m), şemsîya (m)

şey: 1) çî (n), teba (n) 2) ewk, neha, emin, nim (n), rim (n), çîk (n)

şimşek: bilusk (n), virsik (n), vire (n)

şişman: qelew, -e; ganûgoştin, -e; goştin, -e; şîş̧man, -e

şişmek: masayene, pendusayene, nexifìyayene, nepixîyayene, wefirîyayene, wepindofîştene, va bîyene, zepikîyayene, zep bîyene.

şömine: pixêrî (m), şomîne (n), ocaxe (m)

şubat: sibate $(\mathrm{m})$, gucige $(\mathrm{m})$

şüphe: guman (n), şik (n)

tabanca: dabançe (n), şeşadir (n), şeşderb (n), howtetîr (n), piştol (n)

tabut: tabut (n), mafa (m)

tahliye: 1) talkerdiş (n), vengkerdiş (n) 2) texlîya (m), veradayîş (n) (n)

takım: 1) taxim (n), kome (m) 2) ekîpe (m) 3) (giysiler için) taxim (n), qat

takke: kilawe (m), kulike (m)

taklit: bêzarî (m), teqlîd (n), îmîtasyon (n), ase (n)

takunya: qapqapik (n), nalên (n)

takvim: serrname (n), teqwîm (n)

talik: peydeeştiş (n), taloq (n) 
tane: tene $(\mathrm{m})$, hebe $(\mathrm{m})$

tanım: pênas $(\mathrm{n})$, terîf $(\mathrm{n})$

tanıma: şinasnayîş (n), naskerdiş (n), şekerdiş (n)

Tanrı: Homa (n), Ellah (n), Olî (n), Heq (n), Reb (n), Rebî (n), Comerd (n), îlah (n)

taraf: het (n), perr (n), pol (n), hêm (n), qol (n), teref (n)

tarla: hêga (n), zime (n)

tartı: 1) giranî (m), giranîye (m) 2) haceta sentişî (m) 3) peyme (n), mîqyas (n)

taş: kemere $(\mathrm{m})$, kerra $(\mathrm{m})$, sî $(\mathrm{m})$; kuçe $(\mathrm{m})$, bere $(\mathrm{m})$, xirxe $(\mathrm{m})$

tat: tehm (n), lezet (n), ekil (n)

tek: 1) tek (mat), yew 2) tena 3) fert 4) çi, tu; qet yew

teke: kel (n), kelce (n); hevûr (n)

tekne: kurne (m), kurane (m), darên (n), topike (m), tekna (m)

tekrar: reyna, fina, hewna, gilangna, donimna, derbna, dorna, şopna, qorna, defana, tepîya, ancî, ancîna, neqilna, newe ra, newede ra, tekrar

temel: 1) binge (n), binaşe (n) ; bin û binaşe, binyat (n), hîm (n), esas (n) 2) bingeyên, -e; bingeŷ̂ (n)

tepe: qil (n), gil (n), gir (n), tepe (n), tum (n), pul (n), lewe (n), til (n), tirp

tercüme: açarnaye $(\mathrm{n})$, açarnaya $(\mathrm{m})$, açarnayî $(\mathrm{m})$, açarnayîye $(\mathrm{m})$; çarnaye $(\mathrm{n})$, çarnaya $(\mathrm{m})$, çarnayîye $(\mathrm{m})$; tadaye $(\mathrm{m})$, tadaya $(\mathrm{m})$, tadayîye $(\mathrm{m})$ ; tercume (n), agêrnaye (n), agêrnayîye (m)

testi: destî (n), dore (n), meru (n), kuz (n), cer (n)

teyze: yay $(\mathrm{m})$, yayke $(\mathrm{m})$, xale $(\mathrm{m})$, xalike $(\mathrm{m})$, xalete $(\mathrm{m})$

tokaç: banku (n), kone (n), şonik (n), darçe (n), darsoq (n), topîç (n), daqoq (n)

tokat: çopole $(\mathrm{m})$, lekmate $(\mathrm{m})$, lapate $(\mathrm{m})$, lamate $(\mathrm{m})$, şîmaqe $(\mathrm{m})$, şeqame $(\mathrm{m})$, şîlpaxe $(\mathrm{m})$, şîlpate $(\mathrm{m})$, sîle $(\mathrm{m})$

topaç: gerîneke $(\mathrm{m})$, girike $(\mathrm{m})$, guvike $(\mathrm{m})$, mozike $(\mathrm{m})$, vizike $(\mathrm{m})$, soqa $(\mathrm{m})$, qaqe $(\mathrm{m})$, lore $(\mathrm{m})$, meymune $(\mathrm{m})$, delame $(\mathrm{n})$, topaçe $(\mathrm{m})$

topal: leng, -e; topal, -e; çul, -e; çulqaf, -e 
torba: tewre (n), turik (n), pêlek (n) ; kîse (n), kîsik (n) (n)

trampa: pêvurîn (n), seraservurnayîş (n), seraserbedilnayîş (n), terampe

tüm: pêro, heme, têde, têvter, top, kulî

tüy: purt (n), purtik (n), pirç (n)

uğurböceği: xalofir (n), xalxalok (n), xalohemze (n), bawkalik (n), dapîreke (m), lulikê oxirî (n), bext (n), koşkar (n), medîma (m), molmolike (m)

umumi: pêroyî, hemeyî, umûmî

uygun: munasib, -e; musaîd, -e; cade; destdayî, -ye; destdaye (n), destdaya $(\mathrm{m})$, bideameya $(\mathrm{m})$, bideameye $(\mathrm{n})$, muwafiq, -e

uyuma: hewnaşîyayîş (n), busayîş (n), wutiş (n), xowraşîyayîş̧ (n), xowdeşîyayîş (n), kîştakewtiş (n)

uyuşma: 1) kungbîyayîş (n) 2) engilisîyayîş̧ (n) 3) çengizîyayîş̧ (n) 4) pîrikinbîyayîş

\section{$\ddot{\mathbf{U}}$}

ücret: destmiz (n), ucret (n), heq (n)

ürün: 1) ber (n), mehsul (n) 2) berhem (n), eser (n)

üzgün: dejaya (m), dejayîye (m), dejaye (n), qehirîyaya (m), qehirîyayîye (m), qehirîyaye (n), melul, -e; xemgîn, -e; keribîyaya, keribîyayîye (m), keribîyaye (n)

üzüntü: dej (n), verkewtiş (n), kerb (n), kerbizik (n), keder (n), qesawet $(\mathrm{n}), \operatorname{xem}(\mathrm{n})$

\section{V}

vakit: dem (n), taw (n), hing (n), zeman (n), wext (n), mehal (n), çax (n)

vefat: wefat (n), merg (n), merdiş (n)

\section{Y}

yaban: yaban (n), çol (n), geme (m)

yabanarısı: zerqete $(\mathrm{m})$, pîzange $(\mathrm{m})$, mêsa çeqere $(\mathrm{m})$

yağış: şilî (m), variş (n) ; vartûvaran (n)

yaka: 1) girane (n), pêsîr (n), yaxe (n) 2) verî (n) 
yakma: 1) veşnayîș (n), sotiş (n), socnayîș (n) 2) kijkerdiș (n), kijikekerdiş (n) 3) panayîş (n) 4) (katı yakacak için) tanayîş (n)

yamaç: kaş (n), qeraj (n), verarde (m)

yaşlı: pîr, -e; kokim, -e; kal, -e; extîyar, -e; rîsipî, -ye; şikita (m), şikitîye $(\mathrm{m})$, şikite $(\mathrm{n})$

yersolucanı: malik (n), kile (m), kila binê erdî (m), çêle (n), marê şilîye $(\mathrm{n})$, soxulcan $(\mathrm{n})$

yeryüzü: rîyê erdî (n), rîyê erdan (n) ; serê erdî (n), serê erdan (n)

yeşil: hewz, -e; kesk, -e; yaşil, -e

yığın: lode (m), lodike (m), kêşe (m), maxe (m), cema (m), kop (n), dêze (m), koye $(n)$, qûçe $(m)$

yıkma: 1) rijnayîş (n) 2) xilnayîş (n) 3) weşanayîş (n) 4) raşanayîş (n) 5) xeripnayîş (n)

yıldırım: bilusk (n), virsik (n), vire (n)

yırtma: dirnayîş (n), qîşskerdiş (n), çîrkerdiş (n)

yiğit: qehreman, -e; çêr, -e; camêrd (n), camêrdek (n), mêrxas, -e; şek, -e; tuliz, -e; egît, -e

yudum: gepe $(\mathrm{m})$, gume $(\mathrm{m})$, qulte $(\mathrm{m})$, qultike $(\mathrm{m})$, wite $(\mathrm{m})$, firte $(\mathrm{m})$, qilme (m), qilmike (m)

yufka (ekmeği) : nano yowxe (n), yowxe (n), nanê tîrî (n), nanê tewqe (n), nanê sacî (n)

yular: hevsar (n), serhevsar (n), serastar (n), reşme (n), wilar (n)

yumak: ginda $(\mathrm{m})$, gindêlike $(\mathrm{m})$, bulêle $(\mathrm{m})$

yumruk: nuçike (m), kulme (m), kulmike (m), girmike (m), zumzuqe (m)

yüzme: 1) asnawe (m), ajne (m), sobeberî (m) 2) asnawekerdiş (n), ajnekerdiş (n), sobeberîkerdiş (n)

yüzük: engiştane (n), giștire (n), îştane (n), nîştane (n)

\section{Z}

zaman: dem (n), taw (n), hing (n), zeman (n), wext (n), mehal (n), çax (n) zayıf: zeîf, -e; zar, -e; weza, -ye; şehtîyaya (m), şehtîyaye (n)

zirve: tîtik (n), nîçik (n), nîkil (n), gil (n), tap (n), tiltilik (n), tîkil (n) 